\title{
West Virginia climate in relation to weather sensitive industry
}

Roy E. Trent

Robert O. Weedfall

Follow this and additional works at: https://researchrepository.wvu.edu/ wv_agricultural_and_forestry_experiment_station_bulletins

\section{Digital Commons Citation}

Trent, Roy E. and Weedfall, Robert O., "West Virginia climate in relation to weather sensitive industry" (1970). West Virginia Agricultural and Forestry Experiment Station Bulletins. 591T.

https://researchrepository.wvu.edu/wv_agricultural_and_forestry_experiment_station_bulletins/695 @ WVU. It has been accepted for inclusion in West Virginia Agricultural and Forestry Experiment Station Bulletins by an authorized administrator of The Research Repository @ WVU. For more information, please contact ian.harmon@mail.wvu.edu. 


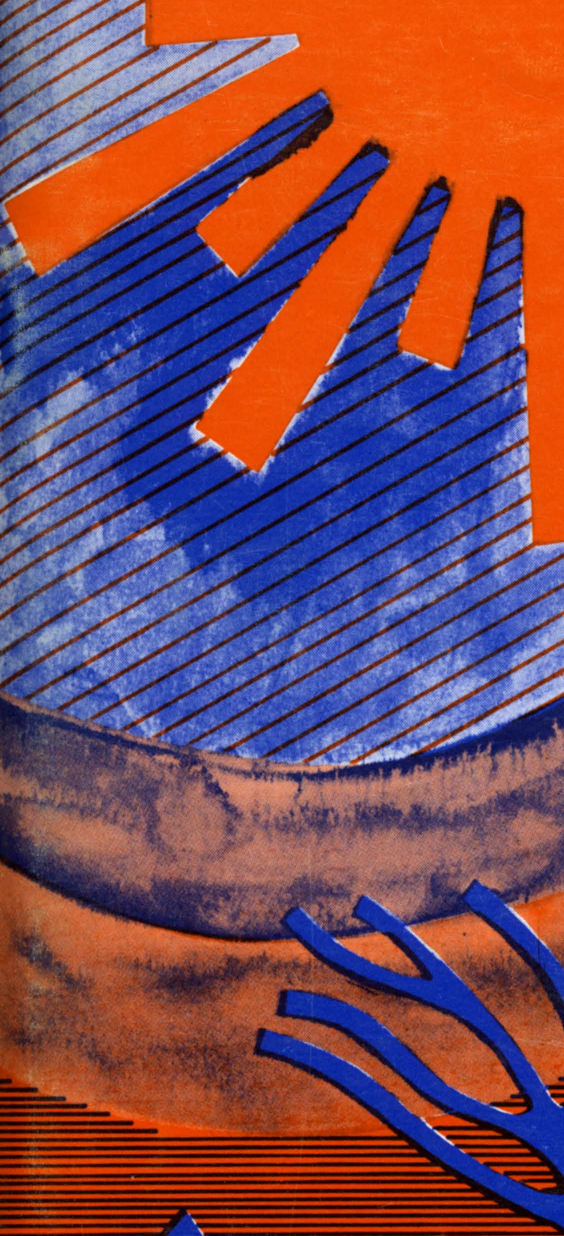

$\sum_{2}^{1} 18 x$
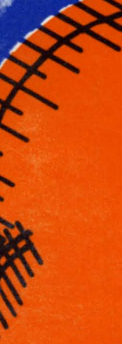

inith।

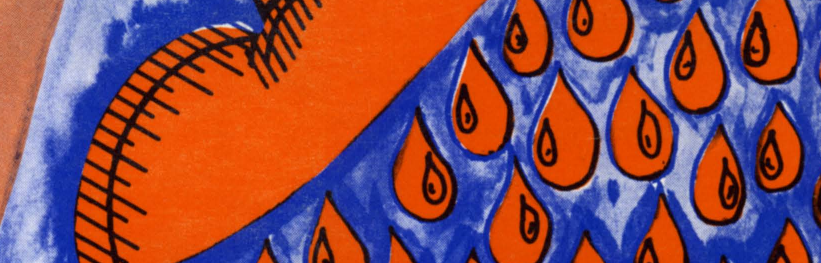

(1) (b) o o

$1,100000(0)$
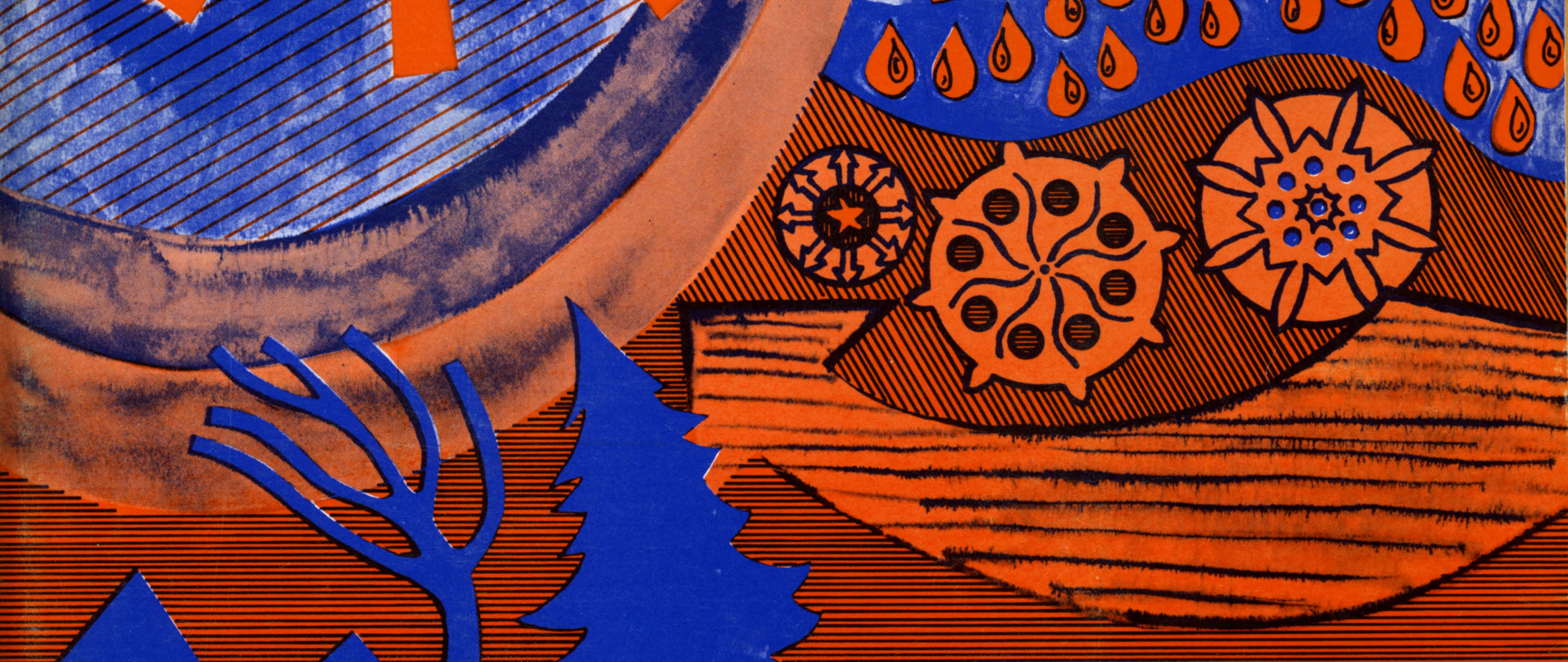

monr

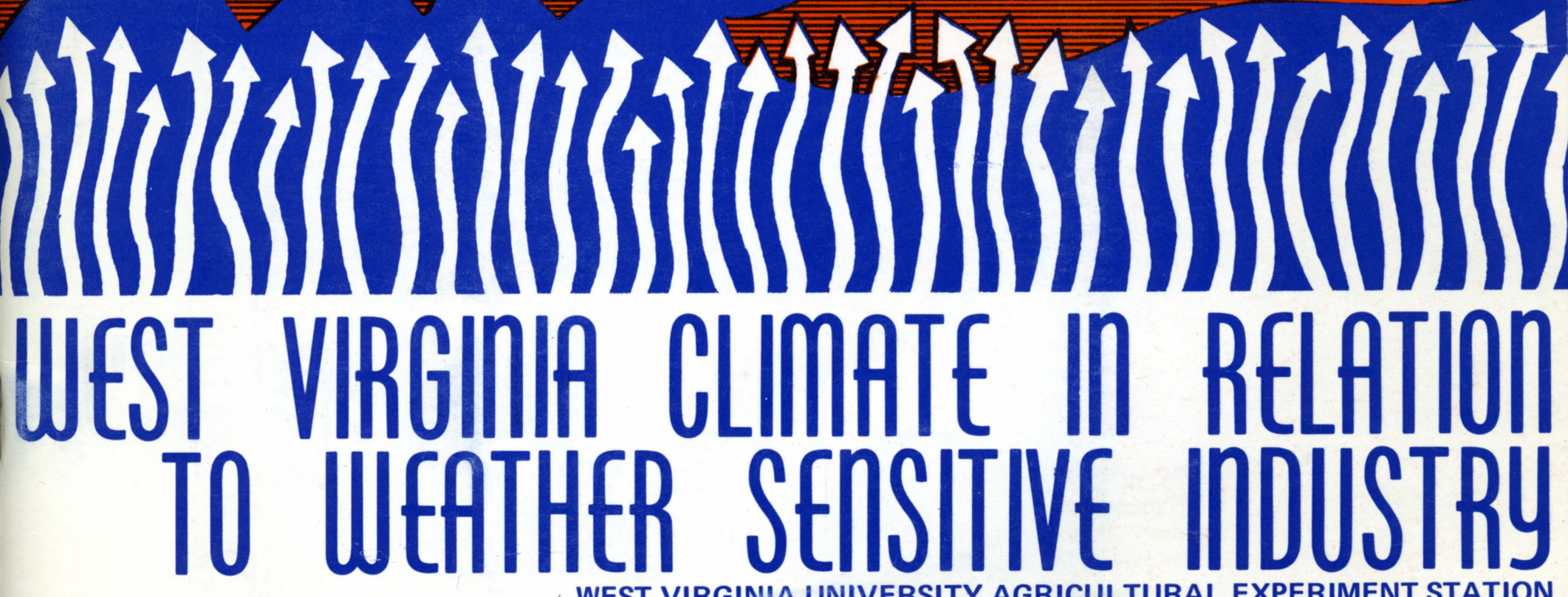


[Blank Page in Original Bulletin] 


\section{Table of Contents}

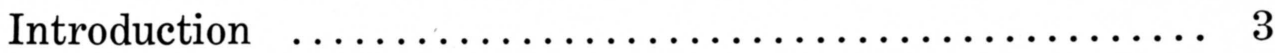

Topographical Effect on Climate $\ldots \ldots \ldots \ldots \ldots \ldots \ldots \ldots . . . \ldots$

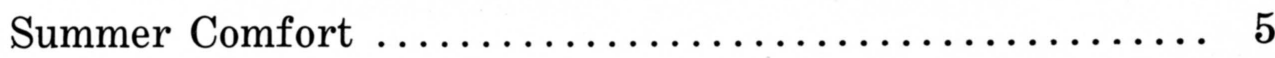

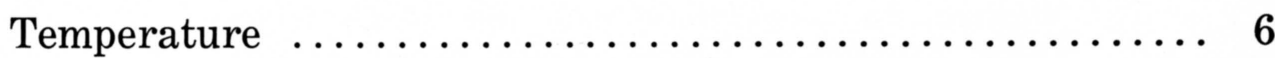

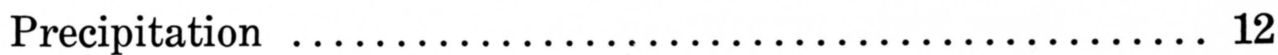

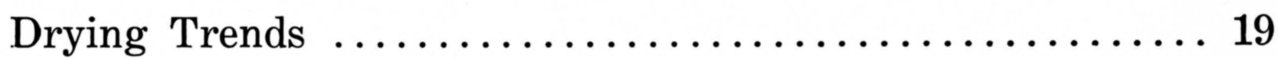

Air Movement ............................. 21

Sunshine, Cloudiness and Fog $\ldots \ldots \ldots \ldots \ldots \ldots \ldots \ldots . \ldots 22$

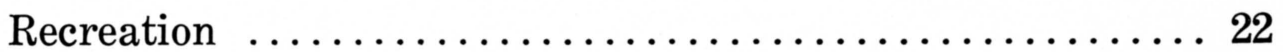

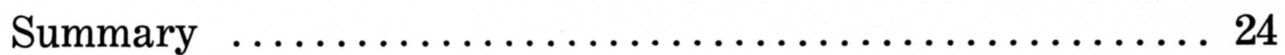

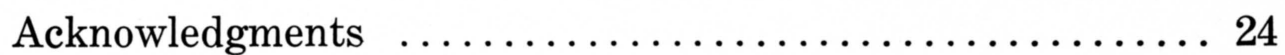

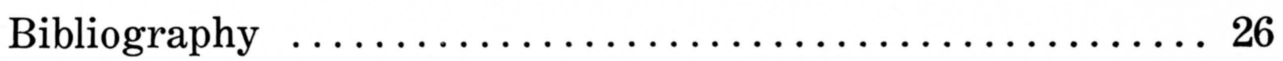




\section{THE AUTHORS}

The authors of West Virginia Climate in Relation to Weather Sensitive Industry are Roy E. Trent, Graduate Research Assistant, West Virginia University; Robert O. Weedfall, State Climatologist in the Weather Bureau, Environmental Science Service Administration, United States Department of Commerce; and W. H. Dickerson, Agricultural Engineer in the West Virginia University Agricultural Experiment Station and Professor of Agricultural Engineering in the College of Engineering.

Prepared by the West Virginia University Agricultural Experiment Station, Morgantown, West Virginia, in cooperation with the Northeastern Forest Experiment Station, USDA Forest Service, Upper Darby, Pennsylvania.

West Virginia UNIVERSITY Agricultural Experiment Station College of Agriculture and Forestry

A. H. Vanlandingham, Director Morgantown, West Virginia 


\section{West Virginia Climate in Relation to Weather Sensitive Industry}

\section{Introduction}

$\mathrm{T}$ HE CLIMATE, as well as the day-to-day weather, is related to such diverse outdoor activities as those carried on in agriculture, the construction industry, forestry operations, or in recreational pursuits.

In the interest of establishing a set of relevant relationships between outdoor activities and the environment, the investigators have made contacts with workers associated with the farm, construction, and timber harvesting industry as well as those concerned with recreational developments. Response was varied. Generally though, the individual expressed a concern with the unfavorable aspects of environment as related to his interest. These inquiries have provided some insight into the impact of weather on outdoor activities and helped to guide the basic direction of this investigation.

In this context, it may be appropriate to keep in mind Thom's comments on the use of weather data (18) :

Meteorological variables are purely physical variables which really apply to nothing but weather. In order, therefore, to use them in non-meteorological applications a means of conversion to the applied variable must be provided so that the climatological prediction can be transformed to the applied variable. This is done . . . by establishing a functional relationship between an appropriate meteorological variable and the applied variable. The problem of finding such a relationship is called the relationship problem. It is often solved jointly by the engineer and the climatologist.

The farmer is concerned with the relationship problem because tillage, planting, cultivating, harvesting and, in some cases, the processing of crops are influenced or controlled by the climate and the weather. The same applies to the forestry industry as felling, skidding, trucking and sawmill operations are constrained by the vagaries of the changing environment. In some respects the construction industry is influenced for the better or worse by the same environmental controls that surround the farmer or operator in the forest. For recreation, the vaca- tioner or hunter may wish for a range of weather that at times may be the antithesis of what is desired by those laboring in the field, the forest or on a construction job.

Human performance, skill and incentive are controlled by environmental conditions to a greater extent than many realize. Clark (2) found that when an individual was directing his maximum efforts to perform well, detrimental climatic effects were most evident. However, the most skilled workers show the least deterioration when subjected to unfavorable conditions. Because workmen set the pace for outdoor operations, it is important to recognize the influence of environment on attitude and performance. In addition to the human aspect, the functional requirements for, and the performance of, machinery and equipment are related to weather condition and the accompanying condition of soils, roads, crops or trees.

The central purpose of this work has been to compile and organize information about the climate of West Virginia into a form which hopefully may be of use to those concerned with various outdoor activities. An attempt has been made to describe some of the relationships mentioned by Thom. The influence of environment on selected outdoor activities is suggested in the discussion of weather data, presented by maps and tables, which follows. It is hoped that the reader may infer other relationships or applications in the context of his own interests. The writers will welcome comments and suggestions as to how the relationship problem may be defined or solved to provide a better understanding of the role of meteorological variables in outdoor activities.

\section{Topographical Effect on Climate}

The range and variability of climate both temporally and spatially are responsible, in a large measure, for the need for a definitive explanation of environmental influences on outdoor activities. In order to understand the climate and day-to-day 


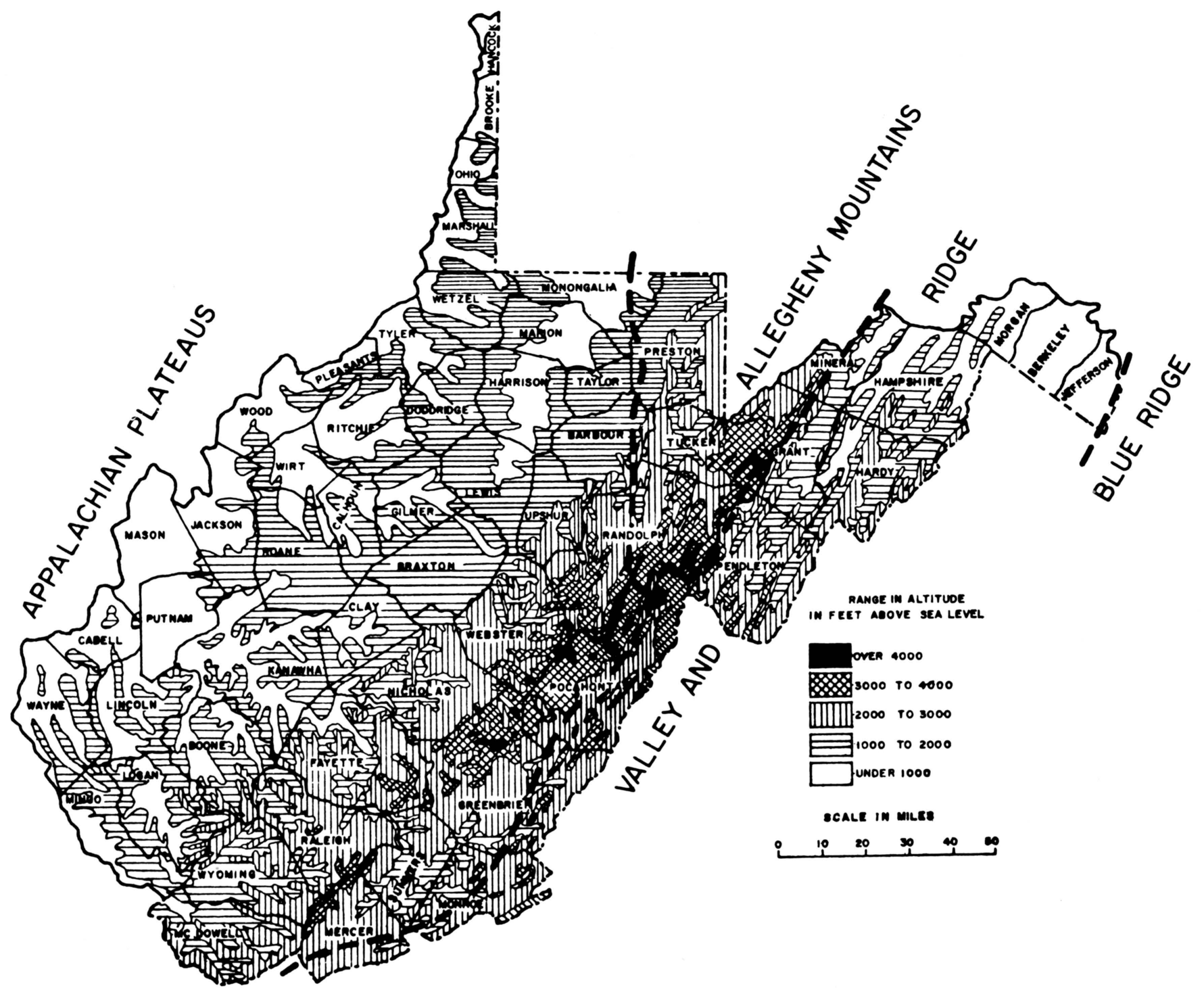

Figure 1. Topographic Map of West Virginia Showing Physiographic Divisions. (Courtesy West Virginia Geological and Economic Survey.)

weather in West Virginia it is necessary to know something of the influence of topography on climate. The State's topography, illustrated in Figure 1, creates a diversity of climatic conditions which is an important aspect of the weather. The latitudinal position imposes a humid continental-type climate characterized by large temperature contrasts between summer and winter. All four seasons are strongly contrasted and their periods of typical weather are nearly of equal length.

The weather also is modified by the generally rugged, hilly terrain and the higher mountain ridges which are mostly orientated from south-southwest to north-northeast. This results in marked variations in temperature and precipitation between the larger mountain, plateau and valley areas, and also to a lesser degree, between hill and valley locations in the same county. During the daytime, air temperature normally decreases with height at about the rate of 3 to $5^{\circ} \mathrm{F}$. per thousand feet. After sundown, the surface of the earth cools due to loss of heat by radiation. The air layers near the surface also cool by conduction, and thus what is called a temperature inversion occurs, usually in the lowest thousand feet. In an inversion the air temperature is cooler near the surface than aloft. This effect is more pronounced in valley bottoms, as the colder air from the hilltops slowly flows downhill shortly after sun- 
down. During the day, the valley bottom is warmest and the hilltop the coolest. Further complicating the distribution of daytime temperature in hilly terrain is the fact that south-facing slopes receive more solar radiation than north-facing ones and become considerably warmer. The distribution of precipitation may vary greatly between hill and valley locations, being dependent on differences in elevation and also on the wind field existing during the time of precipitation.

Because of the topographical effect on the climate the maps which follow should be interpolated and used with caution, particularly in mountainous regions. They generally represent the usual conditions and not the greatest extremes recorded, and variations in the parameters shown occur between hilltops and nearby valley bottoms. A knowledge of the elevation and exposure of the weather station is desirable for transposing the measurements at that station to any other locality.

\section{Summer Comfort}

The Temperature-Humidity Index, based on air temperature and relative humidity, was developed in an attempt to measure human discomfort due to these variables.

J. F. Bosen (1) of the U. S. Weather Bureau proposed the following formula for the TemperatureHumidity Index (THI) :

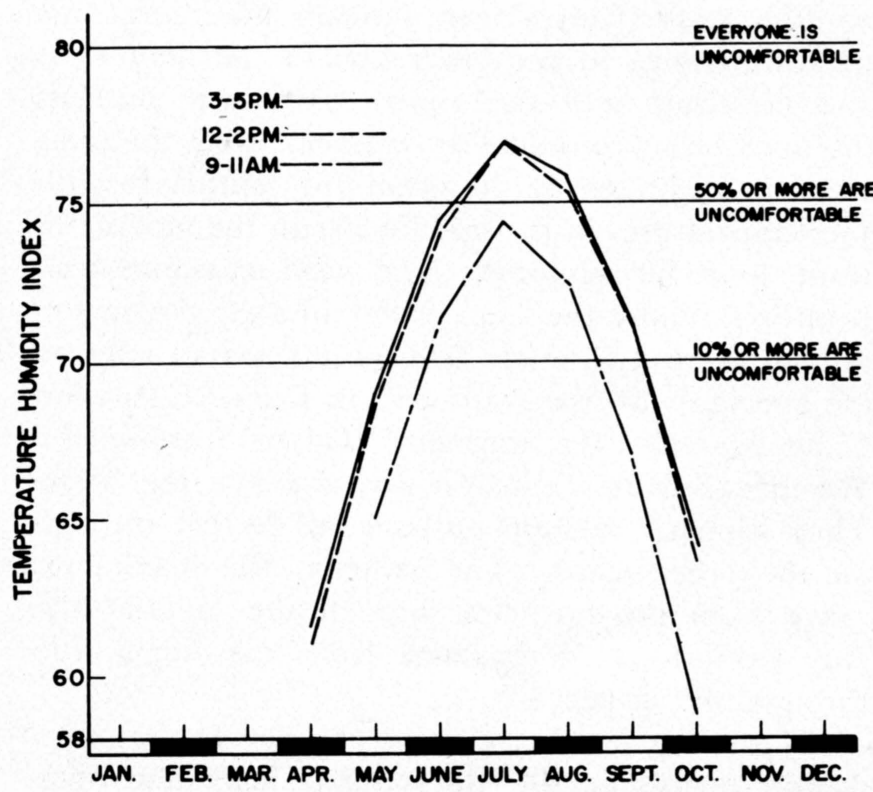

Figure 2. Temperature-Humidity graph for Charleston, West Virginia. (All times Eastern Standard Time $[$ EST $\mid$.)

$$
\mathrm{THI}=\mathrm{Td}-(0.55-0.55 \mathrm{RH}) \quad(\mathrm{Td}-58)
$$

where $\mathrm{Td}=$ Air temperature (dry-bulb thermometer) $\mathrm{RH}=$ Relative Humidity (expressed in hundreths, i.e. $35 \%=.35)$.

When the Index reaches 75 , at least half of the people will be uncomfortable; when it reaches 79 , few if any will be comfortable. Discomfort in general increases rapidly as the Index rises.

Figures 2 and 3 are indicative of average warmweather comfort conditions for Charleston and Elkins, based on the Index. Since these values were obtained from average monthly conditions to temperature and humidity over intervals of three hours, the effects of short-time extremes are obscured. July and August are the least comfortable of the warm season months. Although the noticeable stress is less pronounced in the mountainous area represented by Elkins than in the southwestern plateau of Charleston, Table 1 shows that relative humidity percentages for Elkins average slightly higher in all months of the year. And, although relative humidity is highest near sunrise, this is the time of day when temperatures are lowest, so little discomfort is experienced at this time.

The Index does not take into account the effects of solar radiation and wind speed so its value as a criterion for discomfort experienced in outdoor activities is limited. Fortunately afternoon breezes

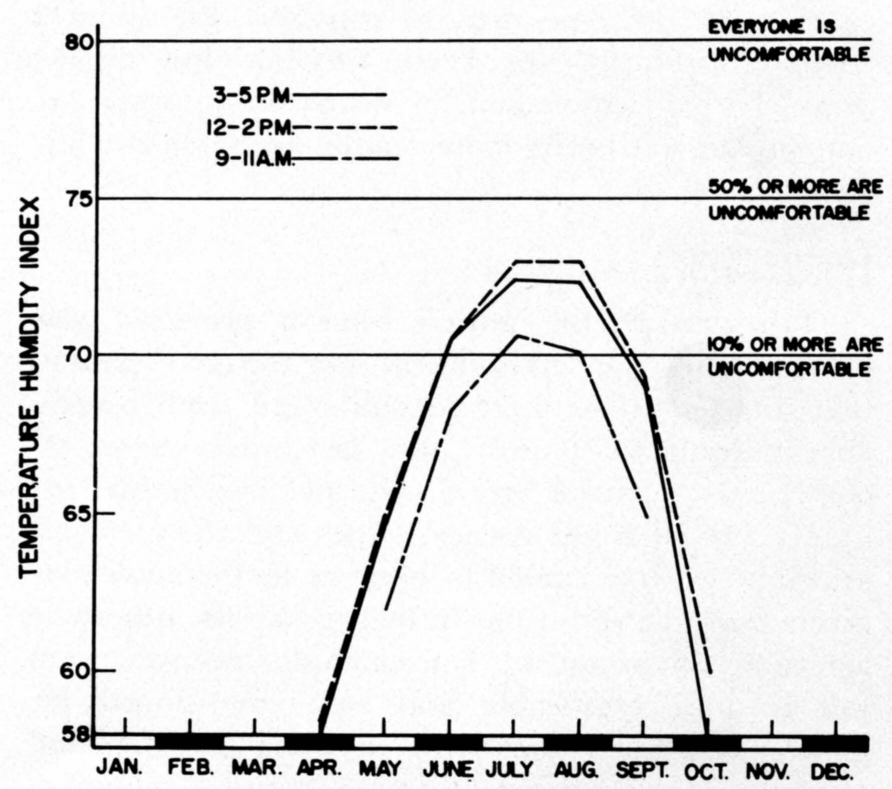

Figure 3. Temperature-Humidity graph for Elkins, West Virginia. (All times Eastern Standard Time |EST|.) 
TABLE 1

AVERAGE RELATIVE HUMIDITY (IN PER CENT) FOR THE MID-SEASON MONTHS

\begin{tabular}{|c|c|c|c|c|}
\hline \multicolumn{5}{|c|}{ ELKINS (Elevation 1,970 feet) } \\
\hline Hours Aneraged & January & April & July & October \\
\hline 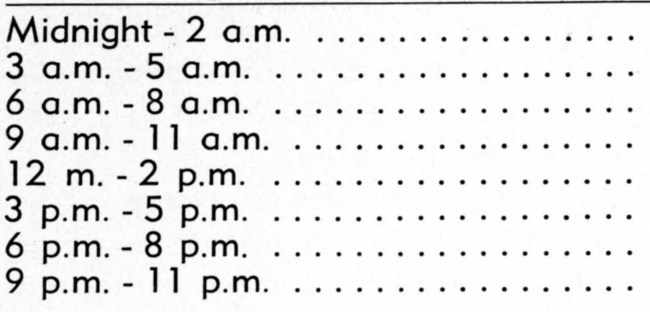 & $\begin{array}{l}78.6 \\
79.7 \\
80.5 \\
77.0 \\
67.3 \\
66.3 \\
73.5 \\
77.6\end{array}$ & $\begin{array}{l}81.3 \\
84.6 \\
82.4 \\
64.0 \\
54.9 \\
54.1 \\
62.1 \\
74.9\end{array}$ & $\begin{array}{l}90.8 \\
92.6 \\
90.2 \\
72.7 \\
62.6 \\
64.1 \\
75.9 \\
87.8\end{array}$ & $\begin{array}{l}87.7 \\
90.1 \\
90.2 \\
73.9 \\
56.0 \\
56.8 \\
73.3 \\
83.8\end{array}$ \\
\hline All Hours $\ldots \ldots \ldots \ldots \ldots$ & 75.0 & 69.8 & 79.6 & 76.4 \\
\hline
\end{tabular}

CHARLESTON (Elevation 939 feet)

\begin{tabular}{|c|c|c|c|c|}
\hline 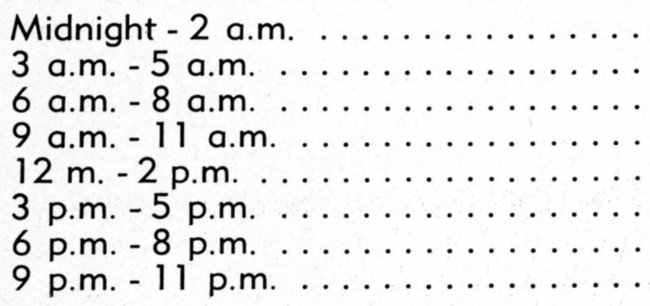 & $\begin{array}{l}75.8 \\
77.2 \\
77.3 \\
72.7 \\
63.6 \\
62.6 \\
68.3 \\
73.1\end{array}$ & $\begin{array}{l}68.6 \\
74.0 \\
73.1 \\
56.8 \\
48.0 \\
46.8 \\
53.0 \\
61.5\end{array}$ & $\begin{array}{l}89.4 \\
92.3 \\
86.5 \\
66.7 \\
55.3 \\
55.9 \\
67.6 \\
82.9\end{array}$ & $\begin{array}{l}82.8 \\
86.5 \\
86.5 \\
67.4 \\
51.9 \\
50.7 \\
64.6 \\
76.4\end{array}$ \\
\hline All Hours & 71.3 & 60.2 & 74.6 & 70.9 \\
\hline
\end{tabular}

NOTE: All hours Eastern Standard Time (EST).

are prevalent in the Appalachian region, and although the speeds are usually less than 12 miles per hour, they exert an alleviating influence on discomfort of those occupied out of doors.

Data of the type used to construct the comfort charts are limited for West Virginia and nearby areas. To gain equivalent, or nearly so, information, one must revert to the more readily available climatic elements.

\section{Temperature}

Temperature has always been a preferred way of describing the environment for the good reason that singly it is the most adequate and readily available indicator of comfort. Man, machinery, livestock, crops and structures are all affected by thermal extremes and their persistence. Other climatic elements associated with or caused by extreme temperature may accentuate the limiting influence of an otherwise agreeable environment. For example, deeply frozen soil is quite trafficable and well conditioned for ground operations, but with warming morning and afternoon temperatures, thawing turns a nongranular soil into an unstable mire. That same warming trend in summer will evaporate the dew from the grass and help dry the soil to make it firm.
Maps of January and July mean monthly maximum and minimum temperature (Figures 4, 5, 6 and 7) present the average and range of daily conditions expected in these, the coldest and warmest months, respectively. Mean January minimum temperatures range in the lower 20's in the mountains and northeast with the southwestern and southern divisions being considerably warmer. Much the same trend is illustrated by the mean July minimum with the temperatures in the middle 50's in the mountains to the lower 60 's elsewhere. The mean maximum temperatures follow the same trend in that the mountainous Central Climatic Division is always cooler on the average with the Southwestern Climatic Division being generally the warmest. (Figure 8 shows the Weather Bureau's climatic divisions for the State. These climatic division outlines are carried through on the other maps.) For January, the maximums range from the low 40's through the middle 40's. July exhibits a wider range from the upper 70's through the upper 80's.

Depending on that part of the day critical to a specific operation, the minimum or maximum temperature will be of most interest. An activity during the near-noon and afternoon may key on maximum values of temperature, while activities in early morn- 


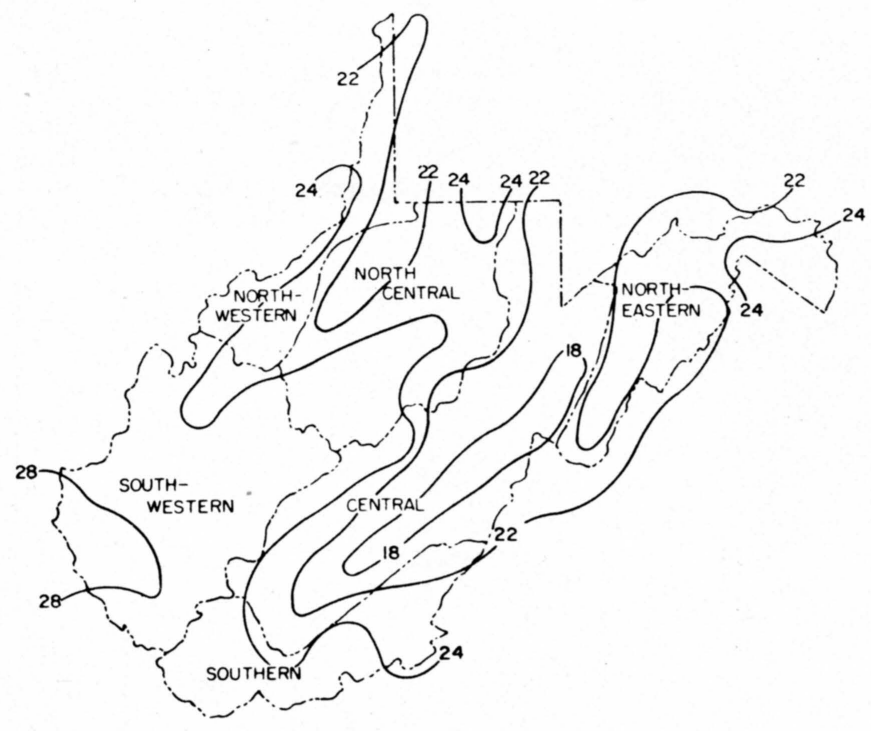

Figure 4. Mean minimum temperatures $\left({ }^{\circ} \mathrm{F}\right)$ JANUARY, based on period 1931-1960. Isolines are drawn through points of approximately equal value.

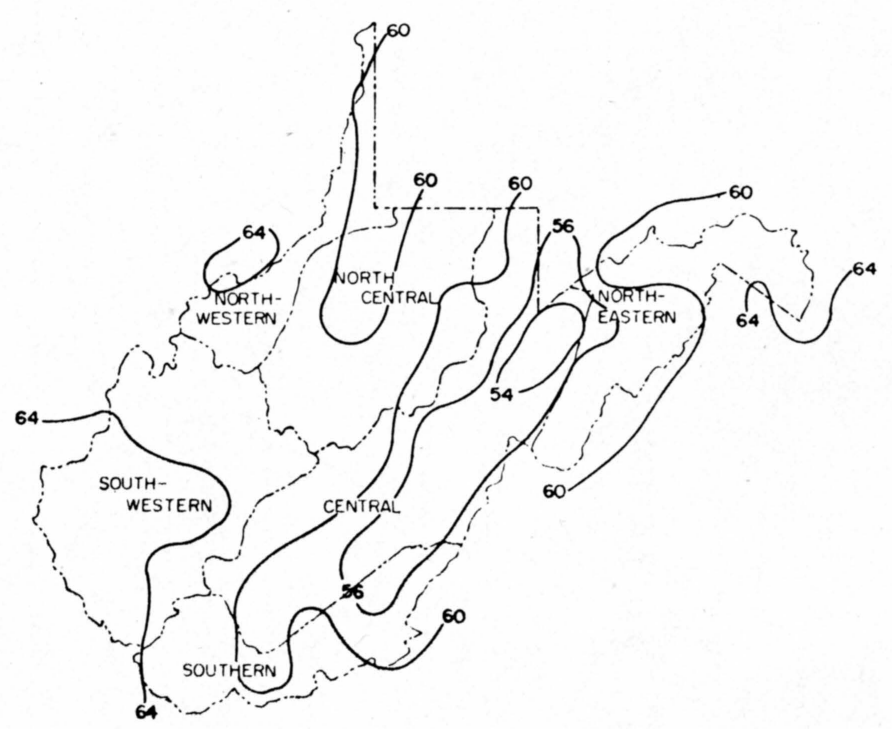

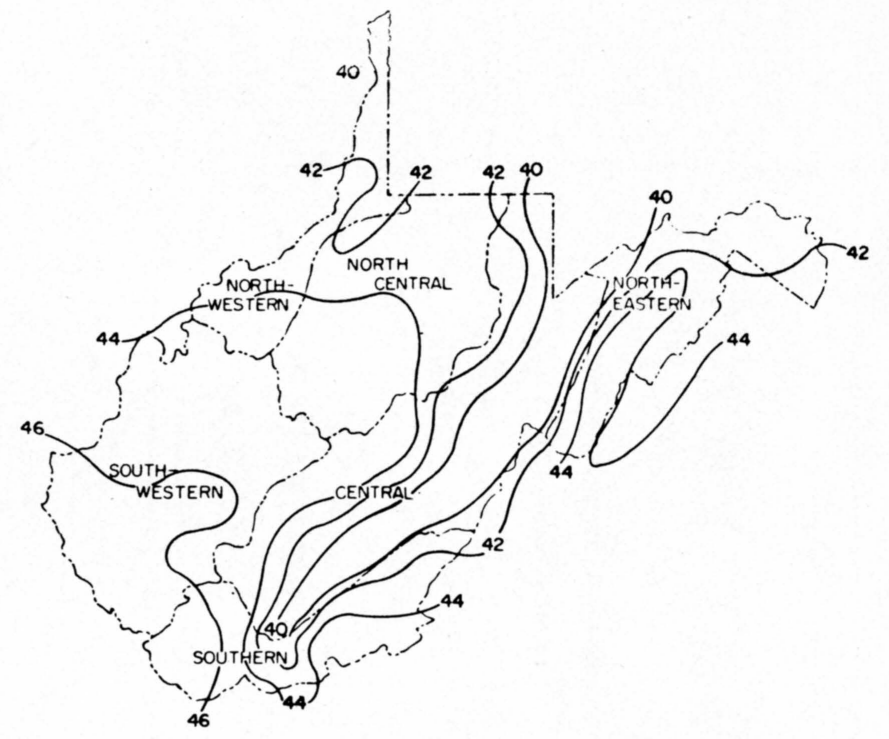

Figure 5. Mean maximum temperatures $\left({ }^{\circ} \mathrm{F}\right)$ JANUARY, based on period 1931-1960. Isolines are drawn through points of approximately equal value.

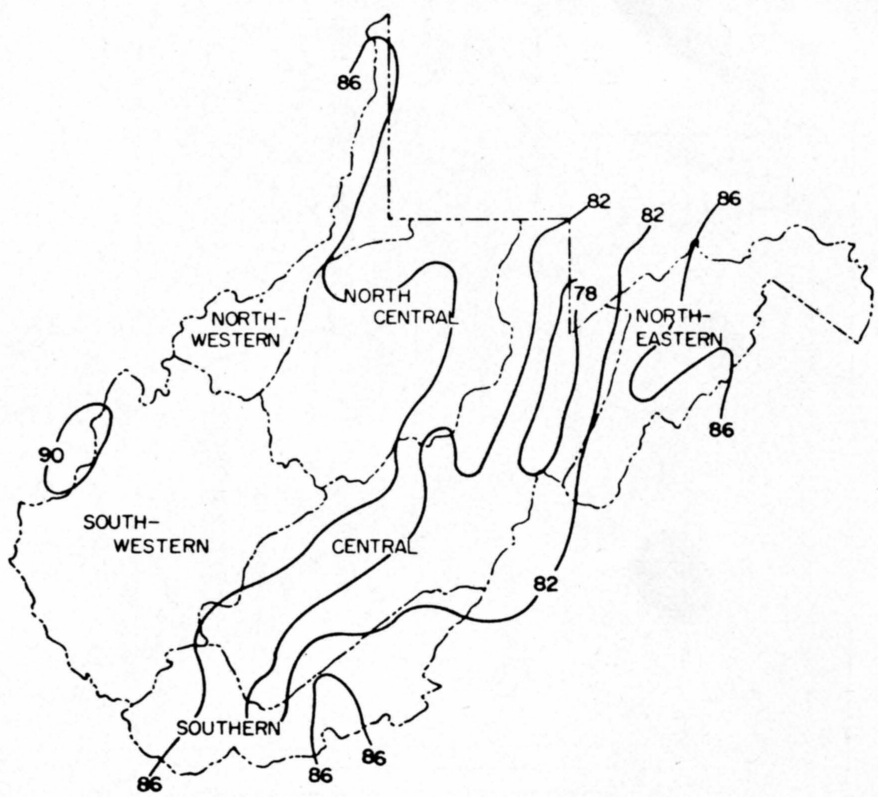

Figure 7. Mean maximum temperatures $\left({ }^{\circ} \mathrm{F}\right)$ JULY, based on period 1931-1960. Isolines are drawn through points of approximately equal value.
Figure 6. Mean minimum temperatures $\left({ }^{\circ} \mathrm{F}\right)$ JULY, based on period 1931-1960. Isolines are drawn through points of approximately equal value. 


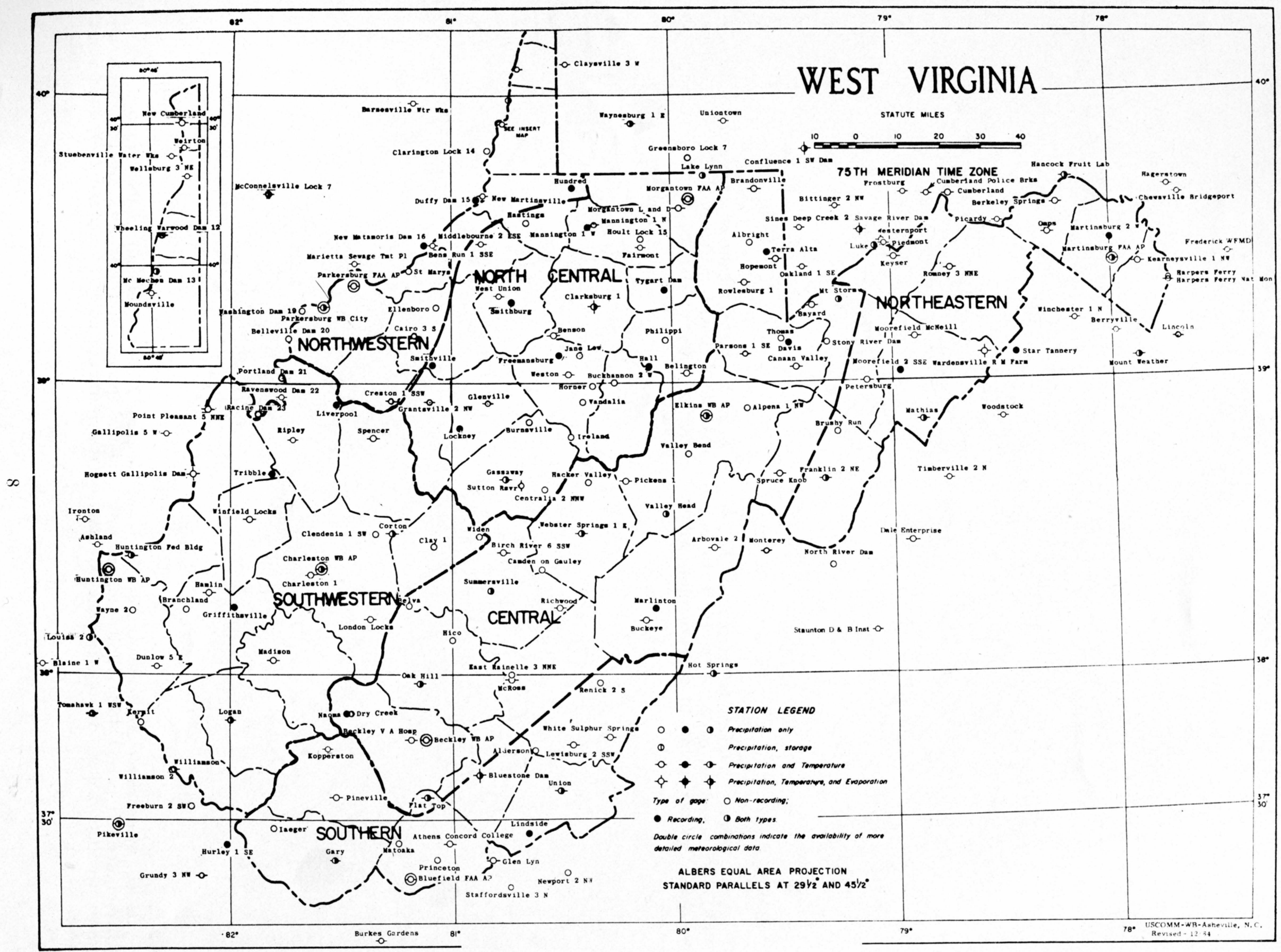

Figure 8. Weather Station Locater Map. 
ing hours may key on the minimum values, since that is the temperature order of likely occurrence.

Another feature of interest to outdoor activities is illustrated by the maps (Figures 9 and 10) giving the number of days with temperatures $32^{\circ} \mathrm{F}$. or lower and $90^{\circ} \mathrm{F}$. or greater. For January there is little variation of occurrences of minimum temperatures of $32^{\circ} \mathrm{F}$. or less throughout the State with 27 days west of the mountains and just slightly more in the East-

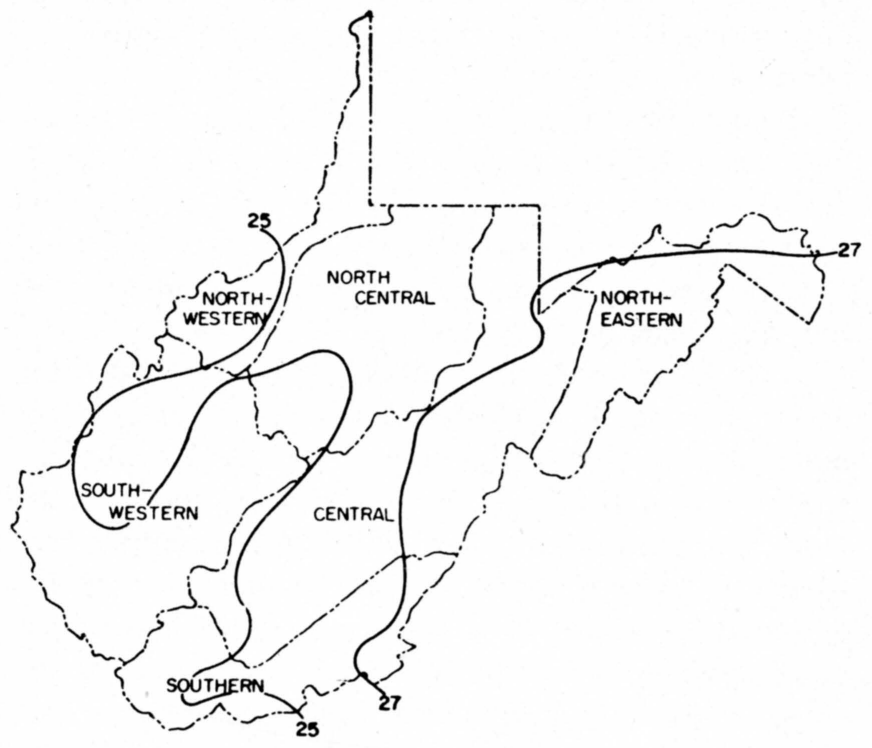

Figure 9. Average number of days in January with temperatures $32^{\circ} \mathrm{F}$ or below. Based on period 1931 1960.

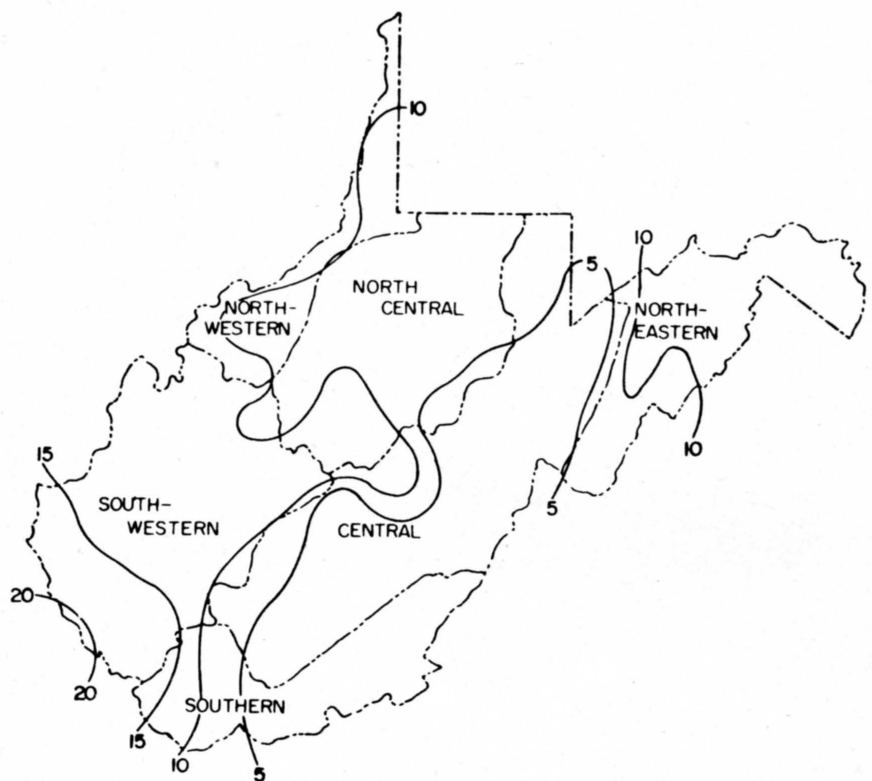

Figure 10. Average number of days in July with temperatures $90^{\circ} \mathrm{F}$ or above. Based on period 1931 1960. ern Panhandle. For July, days with maximum temperatures $90^{\circ} \mathrm{F}$. or greater, the central and parts of the southern climatic division have five occurrences or less. The extreme southern part of the Southwestern Climatic Division has over fifteen occurrences, with a small area over twenty. Possibly more important than the two representative months of January and July are the annual summaries for which the limits of $32^{\circ} \mathrm{F}$. and $90^{\circ} \mathrm{F}$. might signal a work stoppage, or at least serious interference with some activities. The mountainous Central Climatic Division experiences 150 days with temperatures $32^{\circ} \mathrm{F}$. or less with surrounding areas gradually decreasing to below 100 days in the Southwestern Climatic Division (Figure 11). The annual map of number of days with temperatures $90^{\circ} \mathrm{F}$. or greater (Figure 12) indicates that low occurrences prevail in the mountains and the highest number of occurrences are in the Southwestern Climatic Division. This trend illustrates the abrupt change in temperature elements from east to west as opposed to change with latitude.

Other relationships for temperature are secured by various manipulations involving the daily mean temperature. By definition, the daily mean tempera. ture is the average of the daily maximum and minimum. Studies have shown that this is generally a close approximation of an average obtained from 24 hourly readings. Since maximum and minimum temperatures are recorded at over 150 climate stations in West Virginia, examination of variation in detail

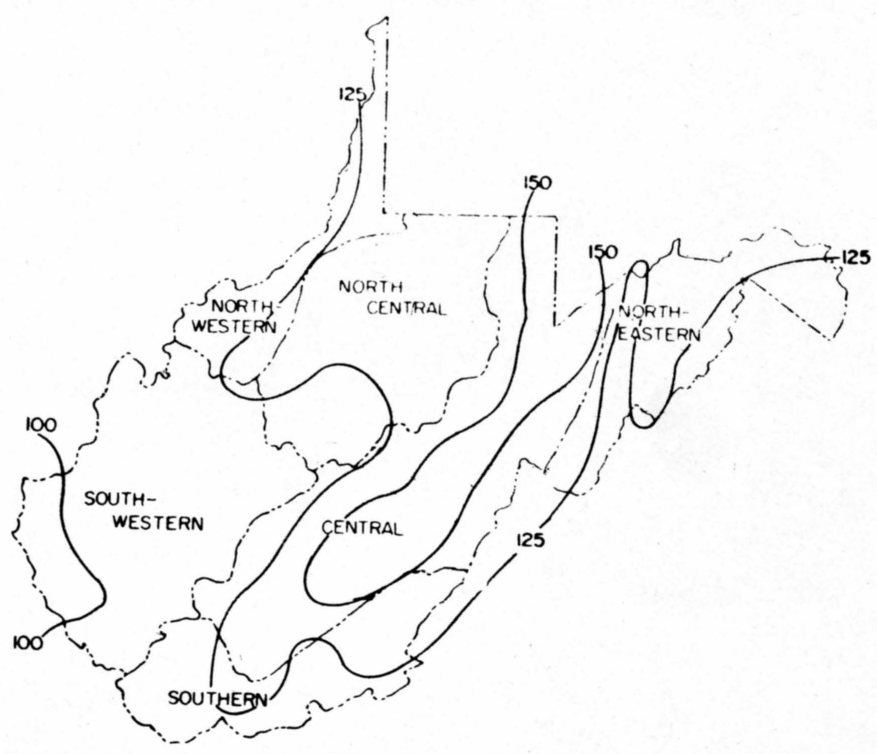

Figure 11. Average number of days annually with temperatures $32^{\circ} \mathrm{F}$ or below. Based on period 1931 1960 


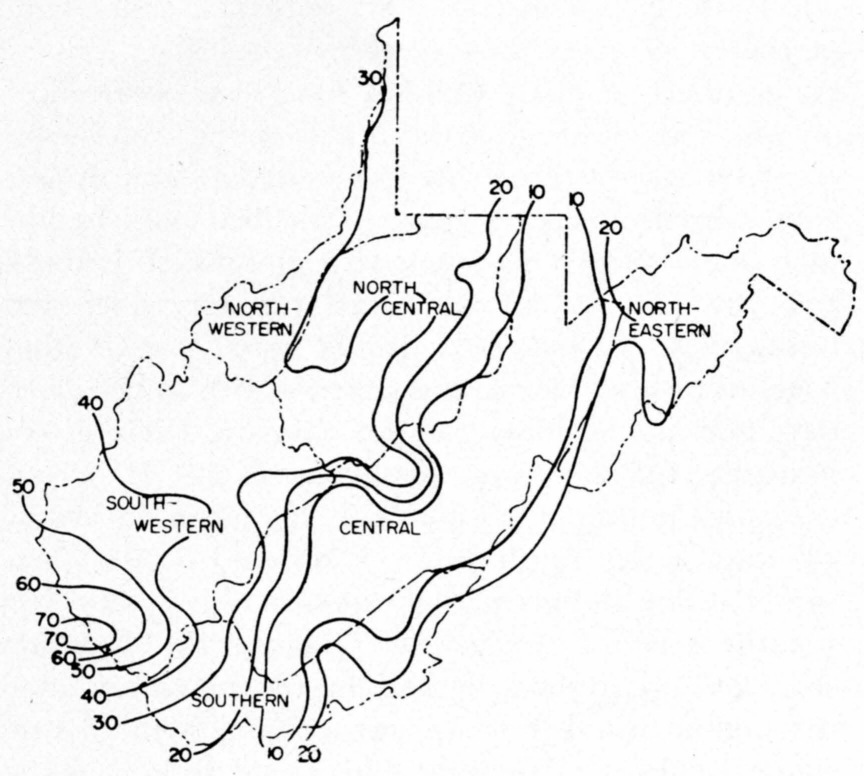

Figure 12. Average number of days annually with temperatures $90^{\circ} \mathrm{F}$ or above. Based on period 1931 1960.

is possible. Four examples using mean temperature are described in the following paragraphs which illustrate uses in air conditioning, heating, estimation of rate or stage of plant growth, and for frost penetration estimates.

Figure 13 is a map which shows average annual cooling degree-days. The cooling degree-day is defined as the difference between $65^{\circ} \mathrm{F}$. and the daily

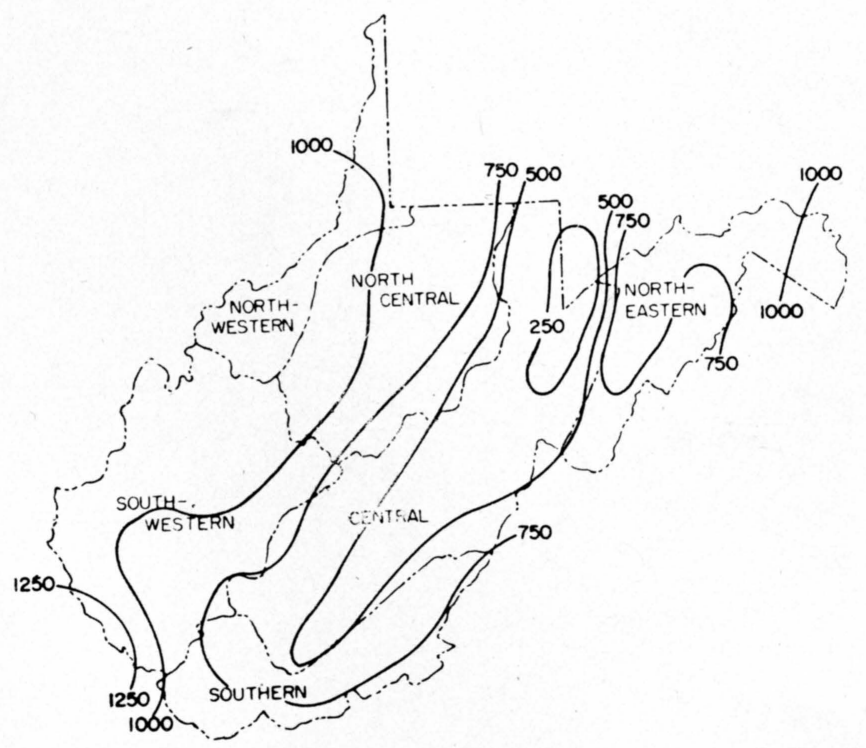

Figure 13. Average annual cooling degree-days (Base $65^{\circ} \mathrm{F}$ ). Isolines are drawn through points of approximately equal value. mean temperature when the latter is above $65^{\circ} \mathrm{F}$. It is used by some engineers to establish air conditioning requirements. Thom (19) has recently pointed out that this degree-day definition, based on dry bulb temperatures alone, adequately explains a substantial amount of cooling load variation and that a more complex variable such as the TemperatureHumidity Index may not always be required. Indoor air conditioning requirements are related to the amount of radiation a structure receives during the day, which is in turn related to the mean daily temperature.

Figure 14 shows average annual heating degreedays, after Dickerson (4). The heating degree-day is defined as the difference between $65^{\circ} \mathrm{F}$. and the daily mean temperature when the latter is below $65^{\circ}$ F. It is universally used by engineers to estimate heating requirements for buildings.

The plant scientist makes use of the growing degree-day which is closedy associated with development and maturation of crops (3). A growing degree-day is defined as the differences between the base temperature and the daily mean temperature when the latter is above the base temperature. A base temperature of $40^{\circ} \mathrm{F}$. is usually used when considering growth units for grasses, legumes and wheat, one of $43^{\circ} \mathrm{F}$. has sometimes been used for orchards, and one of $50^{\circ} \mathrm{F}$. has been suggested for corn. Gilmore and Rogers (11) describe a method of computation for corn which provides close correspondence to accumulation of degree days to stages of growth in corn.

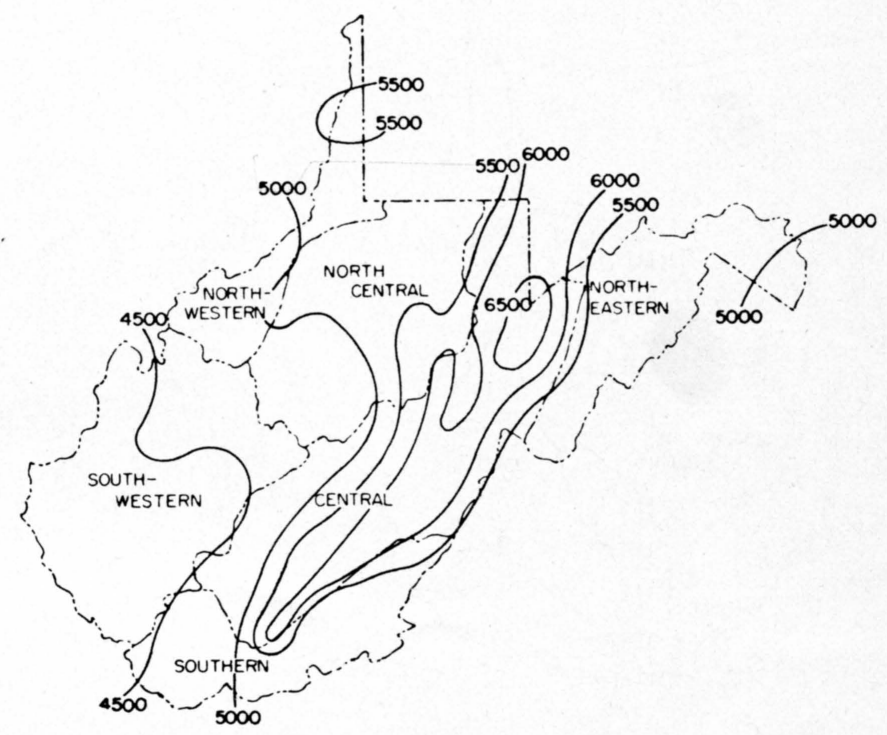

Figure 14. Average annual heating degree-days (Base $65^{\circ} \mathrm{F}$ ). Isolines are drawn through points of approximately equal value. 


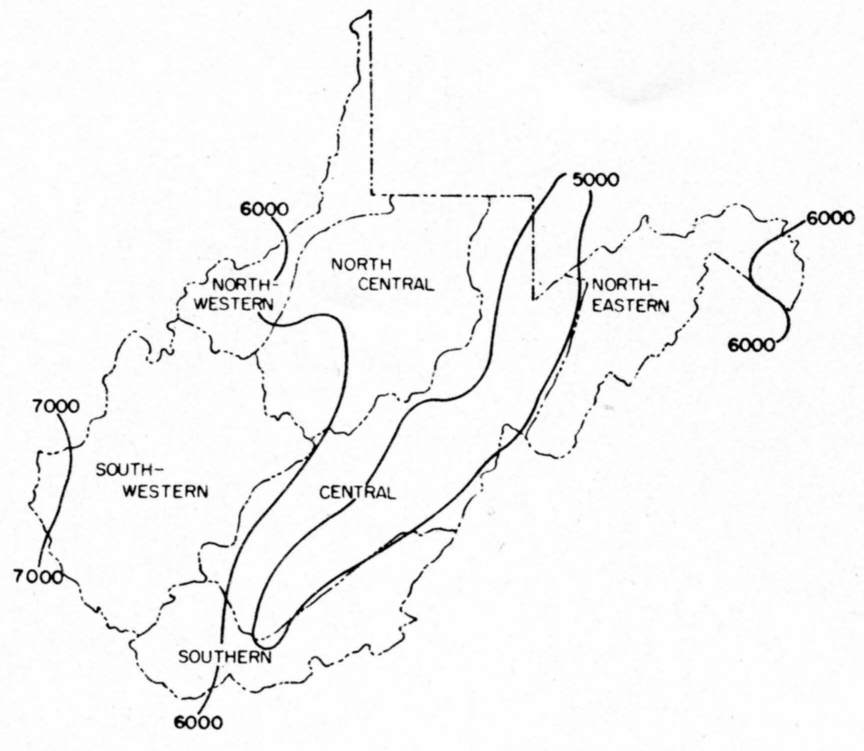

Figure 15. Average annual growing degree-days (Base $40^{\circ} \mathrm{F}$ ). Isolines are drawn through points of approximately equal value.

Figure 15 is a map of annual growing degree-days (base $40^{\circ} \mathrm{F}$.) for West Virginia.

Frost in the ground is important because it affects farming, forestry and construction operations and also because it may damage structures in contact with the soil (5). The occurrence of frost in the ground is dependent on several factors among which are air temperature, soil moisture and cover such as provided by vegetation or snow. A freezing index has been developed (16) to provide a measure of the combined effect of the magnitude and duration of below-freezing temperatures. In this context degreedays are equal to the difference between $32^{\circ} \mathrm{F}$. and the daily mean temperature when the latter is below $32^{\circ} \mathrm{F}$. The freezing index is defined as the greatest continuous accumulation of freezing degree-days. Figure 16 is a freezing index map for West Virginia.

Of particular interest to agriculture is the average date of low temperature occurrences, both in the spring and in. the fall (5), (12). The average date of the last spring freeze ranges from mid-April in the southwestern climatic division to late May in the northern mountain areas (Figure 17). The average date of the first freeze in the fall ranges from midOctober in the southwest and south and far northeast to late September in the mountains (Figure 18) . The average expected number of freeze-free days (sometimes called growing season by the agriculturist) is a valuable guide for scheduling many farm, woods, or construction activities which are affected

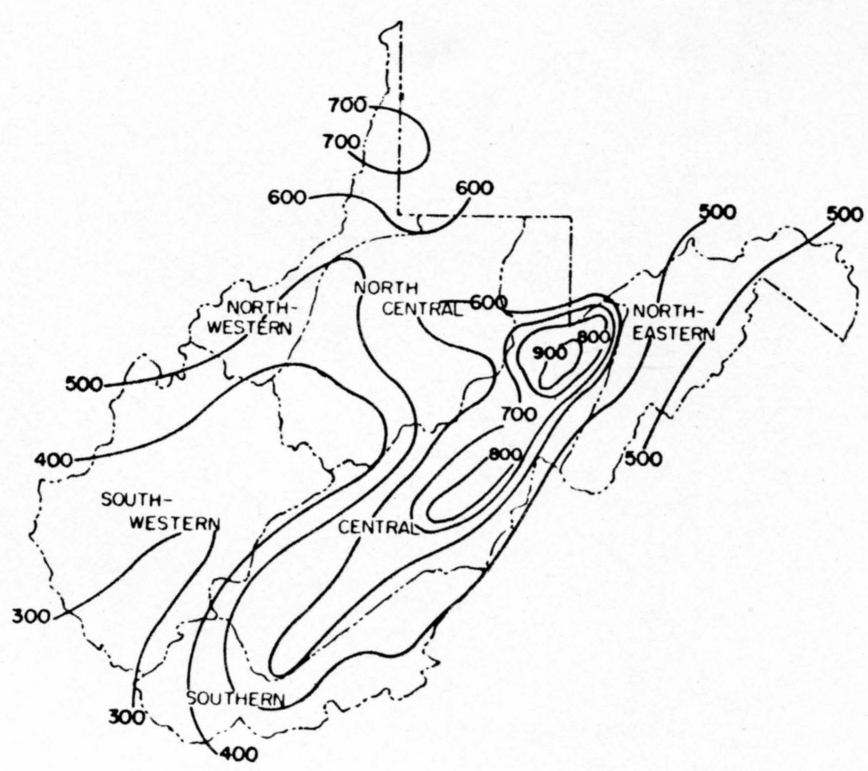

Figures 16. Freezing index in accumulated degree-days (Base $32^{\circ} \mathrm{F}$ ), based on the extreme accumulation during the period 1930-1964 (most of the extremes were accumulated during the 1962 1963 season).

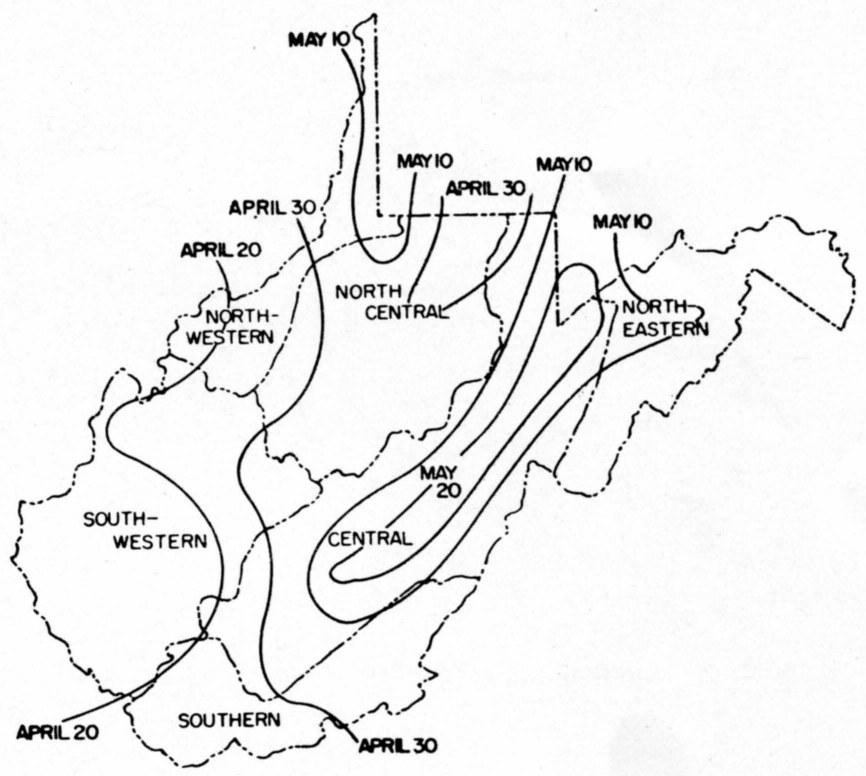

Figure 17. Average dates of last occurrence of $32^{\circ}$ $\mathrm{F}$ or lower in Spring.

by freezing temperatures, and is shown on the map in Figure 19. Figures 20 and 21 show the average last spring and first fall occurrence of temperatures of $28^{\circ} \mathrm{F}$. or lower. A minimum temperature of $32^{\circ}$ F. is frequently reached without doing appreciable injury to vegetation, whereas to reach a temperature of $28^{\circ} \mathrm{F}$. several hours of freezing temperatures have usually occurred. 


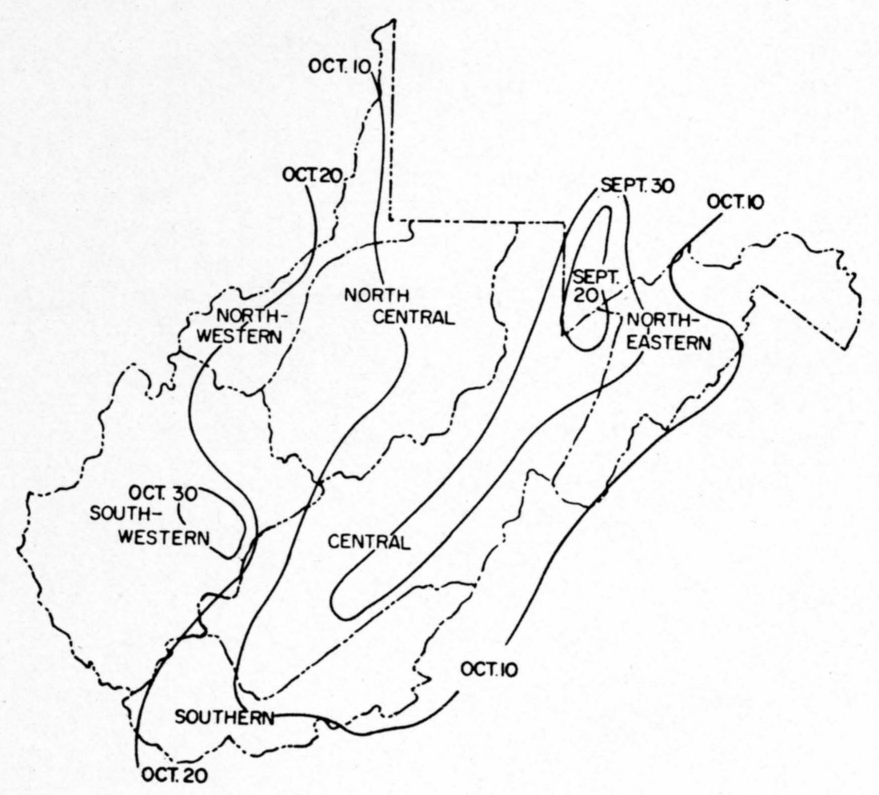

Figure 18. Average dates of first occurrence of $32^{\circ}$ $\mathrm{F}$ or lower in Fall.

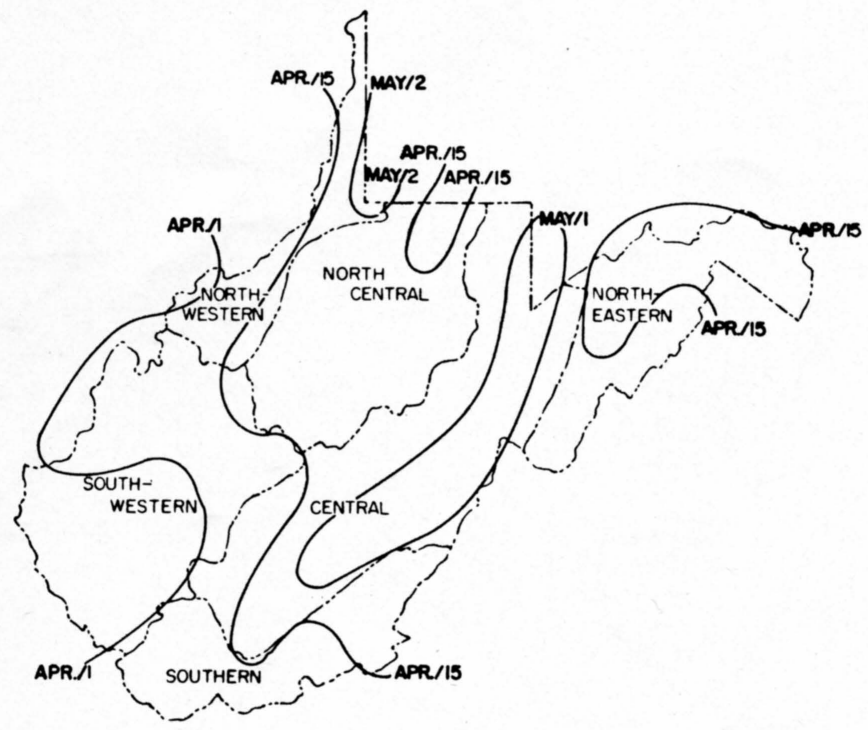

Figure 20. Average dates of last occurrence of $28^{\circ} \mathrm{F}$ or lower in Spring.

\section{Precipitation}

Precipitation is rain, snow or sleet and it is measured in terms of depth, usually in the liquid form. Snow is measured in two ways: the depth of freshly fallen snow within a specified time period (usually one day) is measured with a rule in several locations, or the snow catch in the precipitation

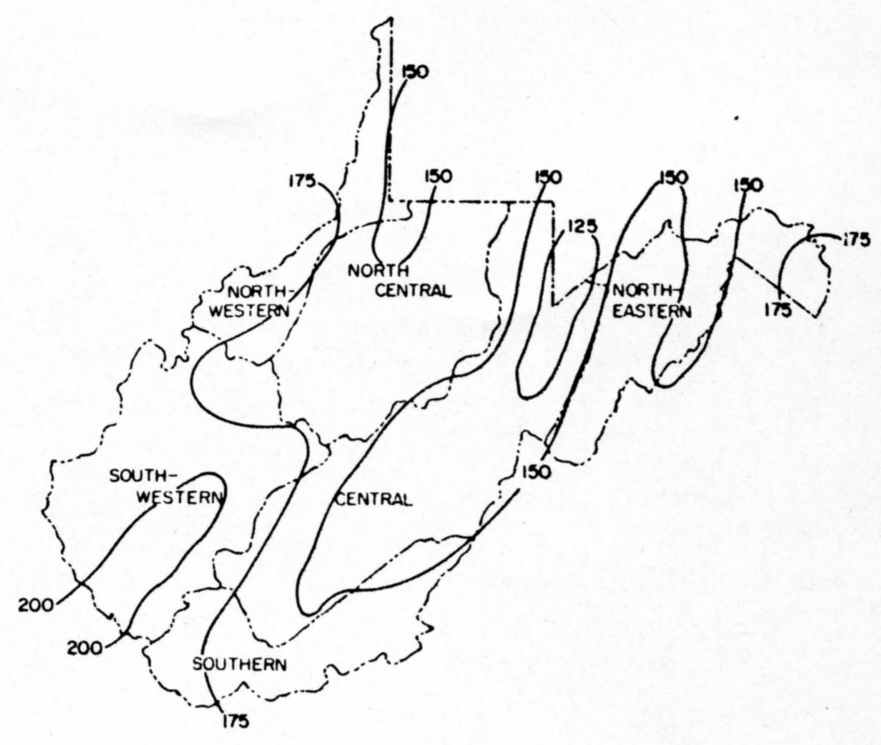

Figure 19. Average lengths of growing season (freeze-free period) in days. Isolines are drawn through points of approximately equal value.

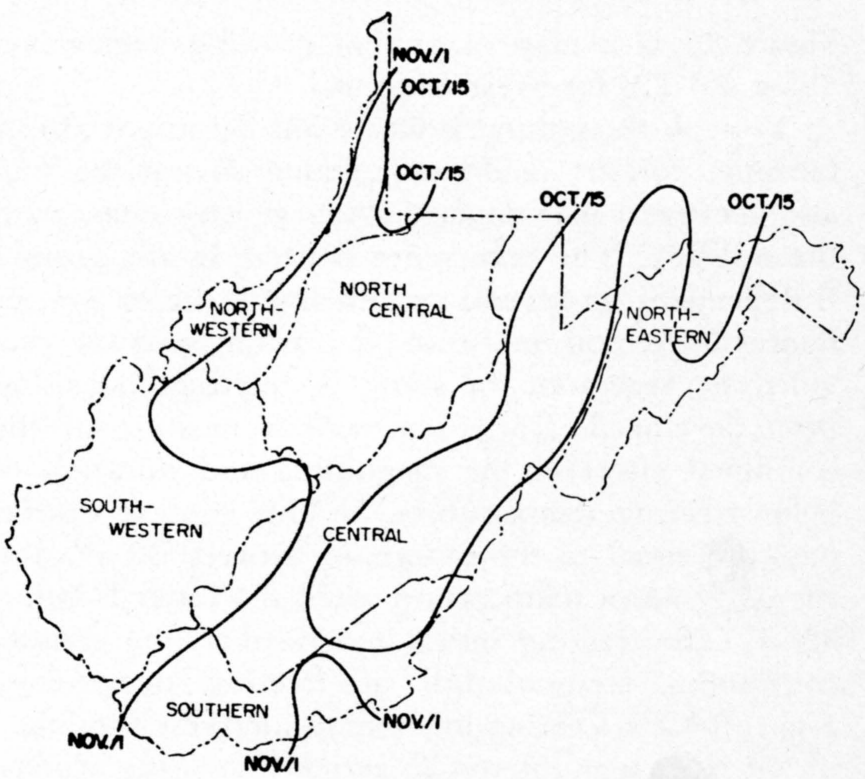

Figure 21. Average dates of first occurrence of $28^{\circ} \mathrm{F}$ or lower in Fall.

gage is melted to get a water equivalent for the snow fall.

Precipitation certainly hampers most outdoor activities, although some recreational activities are dependent on snow. Its influence will always be present, but the limiting effect of this climatic element, as with most, may be reduced for some types of operations with knowledge of its probability in terms of 
diurnal, monthly or seasonal occurrence. Even rainfall of light intensity is usually sufficient to force those engaged in outdoor activities to take shelter for its duration. A work or play stoppage, though undesirable, is not necessarily the ultimate effect: depending on the nature of the activity, residual moisture (sometimes in the form of ice or snow) in and on the soil, machinery, structure, or vegetation very often provides longer lasting problems. The loss of tractionability is one of the most common influences attributable to the residual effect of excessive soil moisture. Snow is often a problem after a storm because of the reduction of the mobility of machines and man. However, the hunter or skier may have been eagerly awaiting the very conditions that cause a hardship on the outdoor worker.

Quite often yearly sums or averages for climatic elements do not adequately explain the monthly or season tendencies. In view of this, maps of average monthly precipitation are shown for October through March. The month of lowest precipitation in most locations in West Virginia is October, due mainly to stagnant atmospheric circulation at this time of year. This stagnation often carries on into November. February is low because the prevailing cold air masses contain little moisture. The annual and monthly maps are shown in Figures 22 through 28. Rainfall for the growing season, May through September, is presented in Figure 29. Rainfall for July (Figure 30) is.included because this month is the highest of the

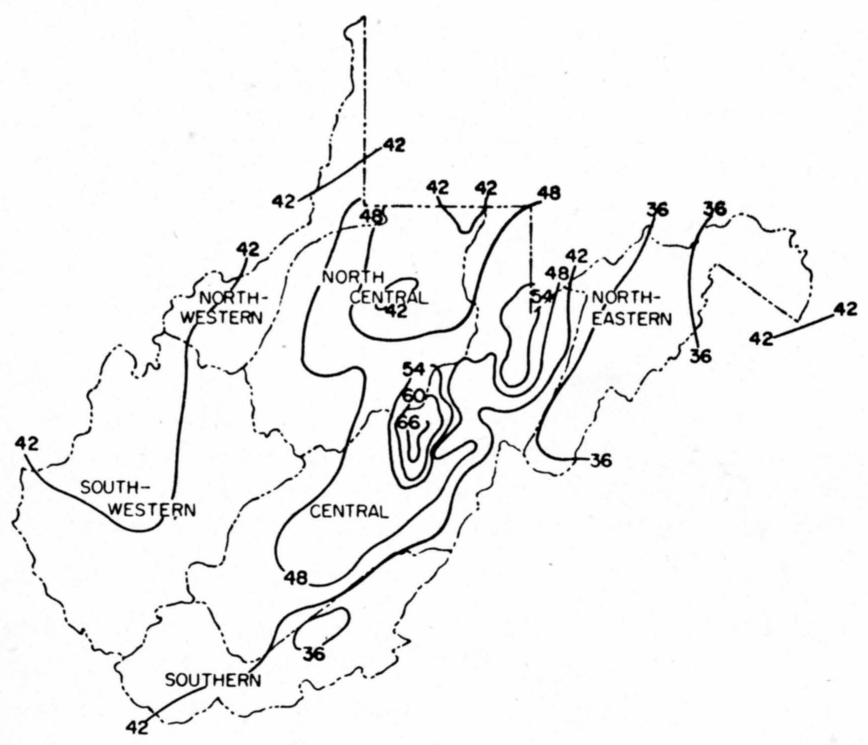

Figure 22. Mean annual precipitation (Inches). Based on period 1931-1960. Isolines are drawn through points of approximately equal value.

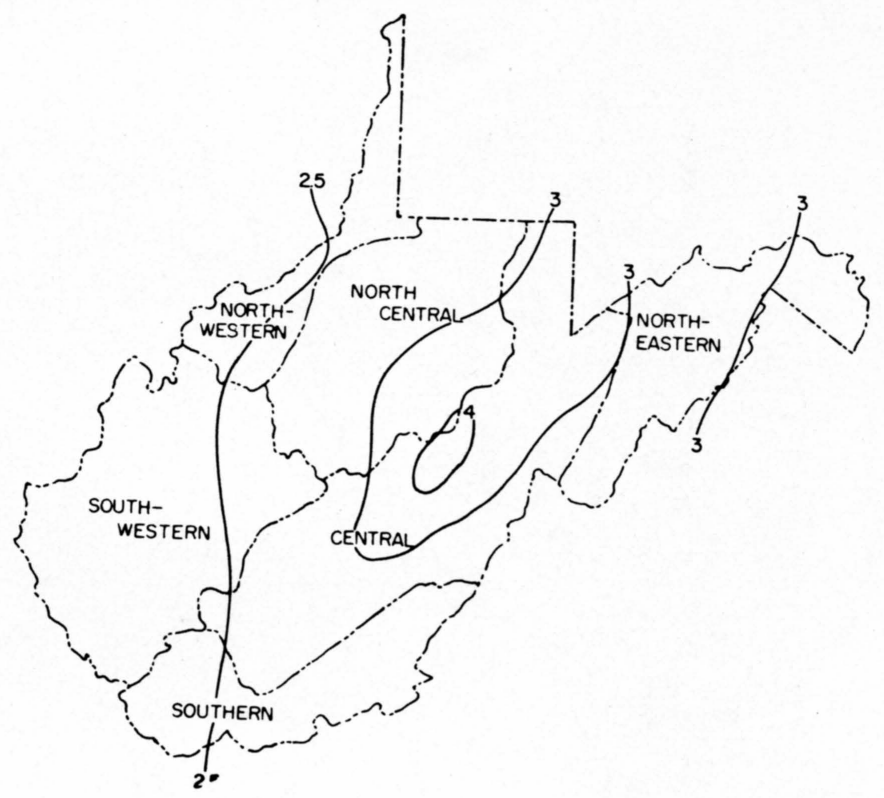

Figure 23. Mean October precipitation (Inches). Based on period 1931-1960. Isolines are drawn through points of approximately equal value.

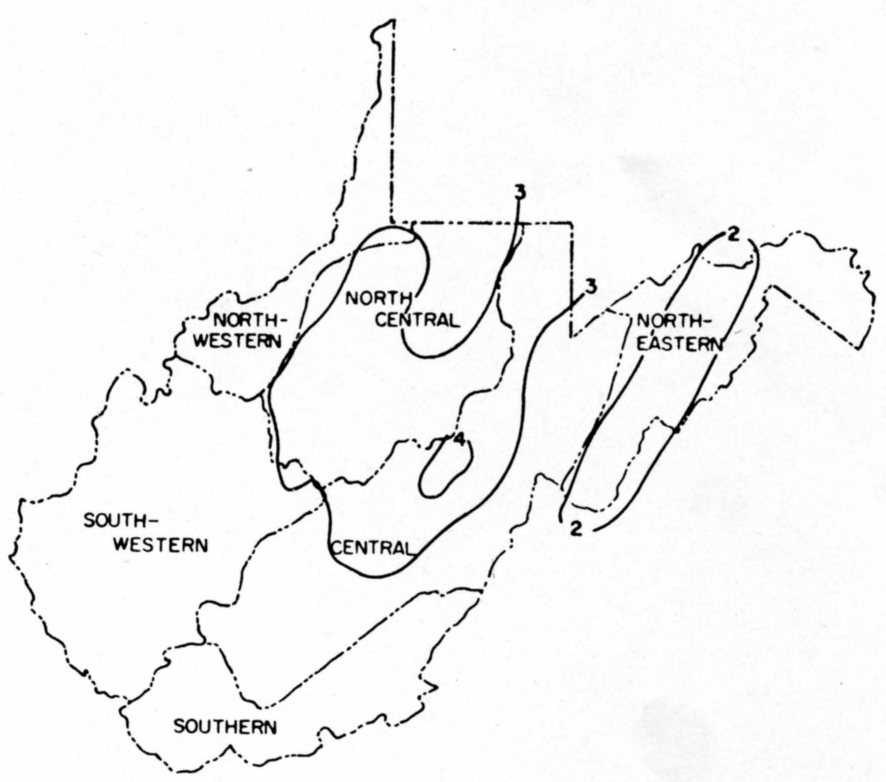

Figure 24. Mean November precipitation (Inches). Based on period 1931-1960. Isolines are drawn through points of approximately equal value.

year (except some stations in the northeastern climatic division have their highest totals in August because of the influence of hurricanes which move along the coast at that time of year).

Hourly precipitation statistics for the Charleston weather station for the midseason months for a period 


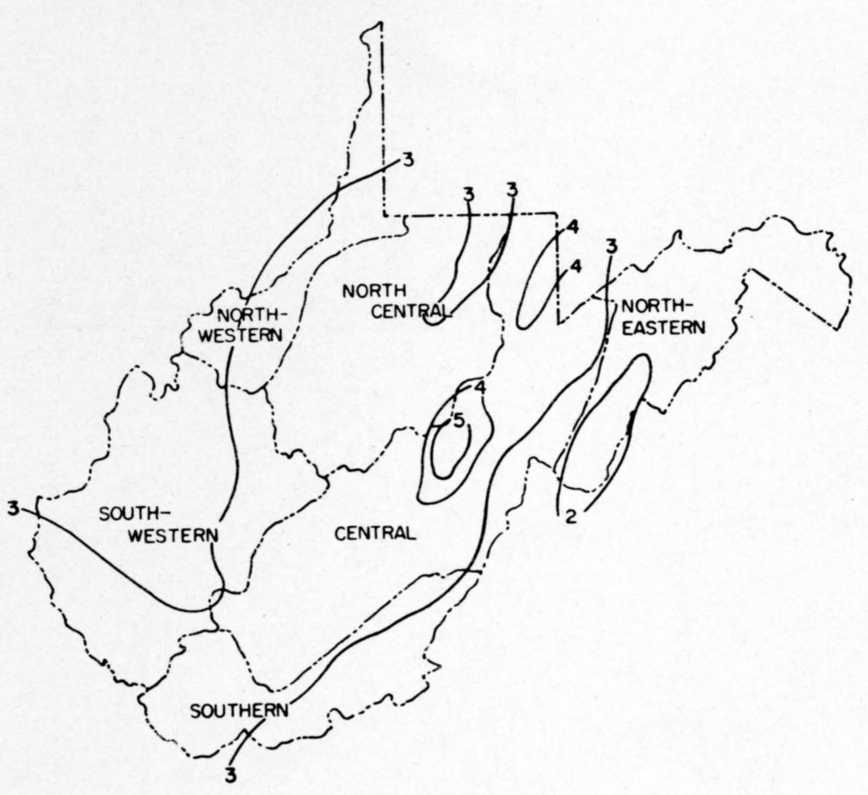

Figure 25. Mean December precipitation (Inches). Based on period 1931-1960. Isolines are drawn through points of approximately equal value.

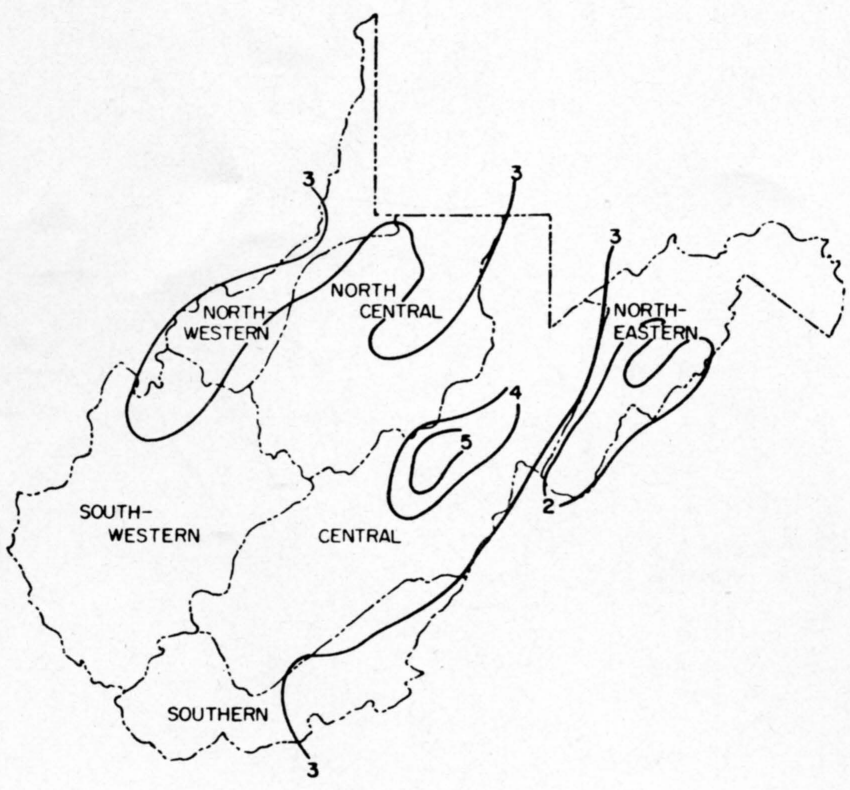

Figure 27. Mean February precipitation (Inches). Based on period 1931-1960. Isolines are drawn through points of approximately equal value.

of 14 years are given in Table 2. The left hand side of the table shows the average number of hours (by hour of the day) with precipitation .01 inch or more. The right hand side shows the average hourly amounts of precipitation for the midseason months. These data may be used for work scheduling and planning various types of outdoor activities. The

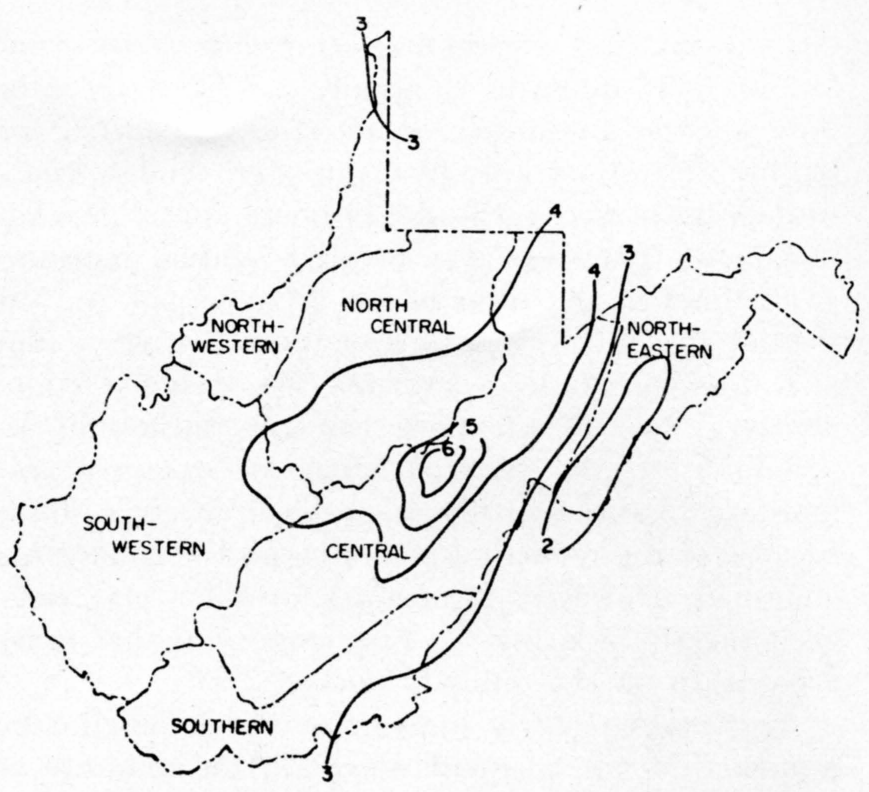

Figure 26. Mean January precipitation (Inches). Based on period 1931-1960. Isolines are drawn through points of approximately equal value.

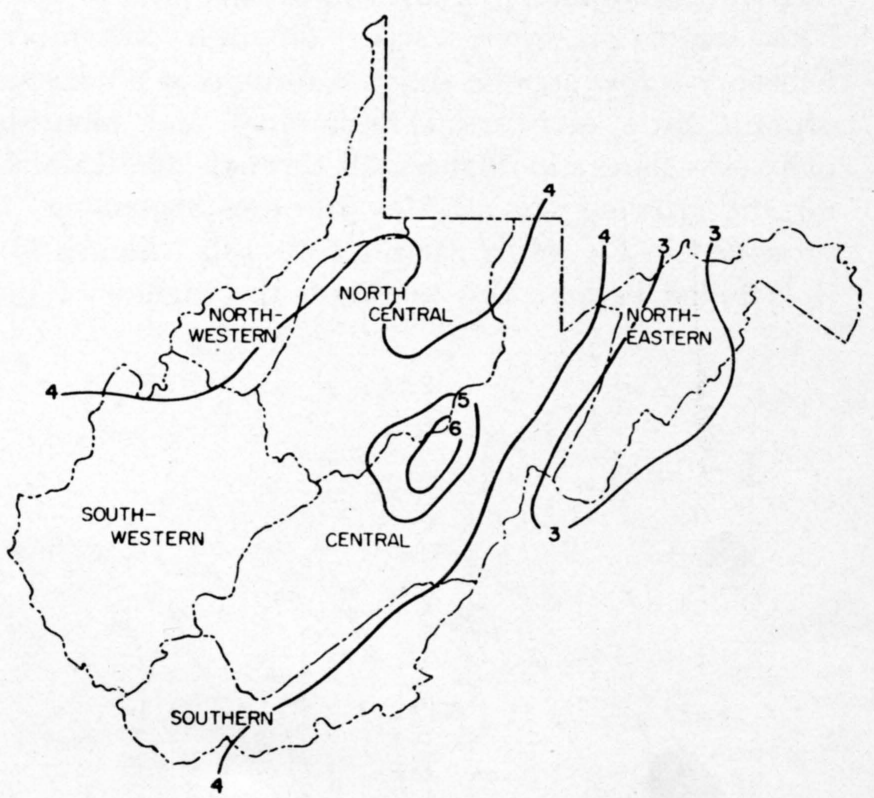

Figure 28. Mean March precipitation (Inches). Based on period 1931-1960. Isolines are drawn through points of approximately equal value.

summer data show that it may be more advantageous to begin work as early as possible and end operations in the early afternoon to avoid the hours of greatest frequency of afternoon showers. Winter data show less differences in occurrences and amounts except that the early mornings, from 1 a.m. until about noon, show somewhat more occurrences and larger 


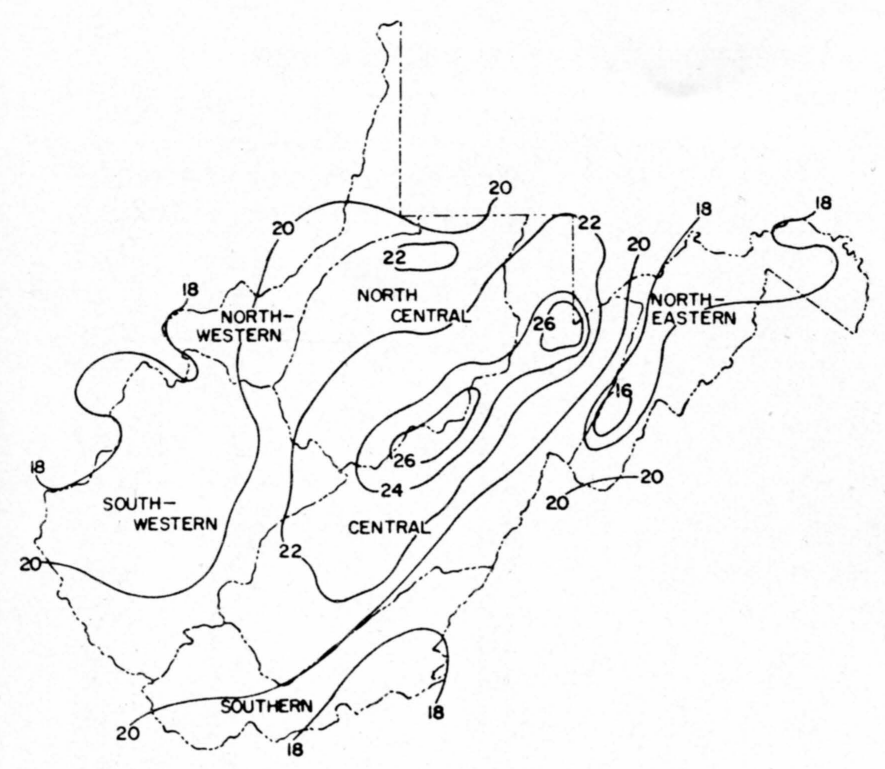

Figure 29. Mean growing season rainfall (May through September). Based on period 1931-1960. Isolines are drawn through points of approximately equal value.

amounts. Scheduling of winter work hours during the later part of the day would permit better working conditions, on the average.

A great deal of summer rainfall is a consequence of thunderstorms. These storms thrive on moist, warm air and release great amounts of energy produced by the latent heat of condensation. Usually 40 to 50 thunderstorm days occur annually at any one locality in West Virginia. The graphs of days with thunderstorms by month (Figure 31 ) show that July has the most. Elkins, representative of the mountain areas, has a tendency to have a higher incidence of thunderstorms than either Charleston or Parkersburg, which are representative of the lower plateau areas.

Lightning is a danger to the outdoor worker or recreationist, and the risk is greater than most people think. The transition from a small summer cumulus cloud to a turbulent electrified cumulonimbus can occur in as little as 30 minutes. On the average, lightning kills some 150 persons, and injures about 250 every year in the United States (22). During the five-year period 1964-1968 in West Virginia (23), four persons were killed by lightning strikes, and ten were injured. Of the four deaths, two occurred on farms, one on a golf course, and one under a light fixture on a front porch. The average death toll is higher for lightning than for tornadoes (which are very rare in West Virginia) or hurricanes.

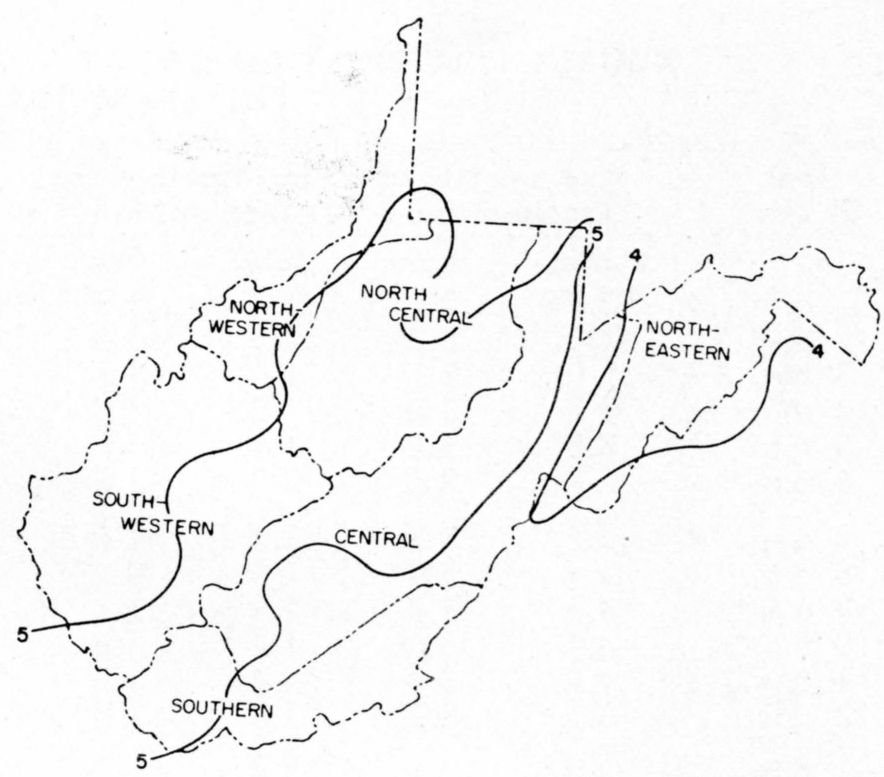

Figure 30. Mean July rainfall (Inches). Based on period 1931-1960. Isolines are drawn through points of approximately equal value.

Warm season thunderstorms are responsible for the heavy local rains that cause flash flooding in the small, steep watersheds that characterize the Appalachian Plateau. Most all record rainfalls of one day or less are associated with some type of thunderstorm.

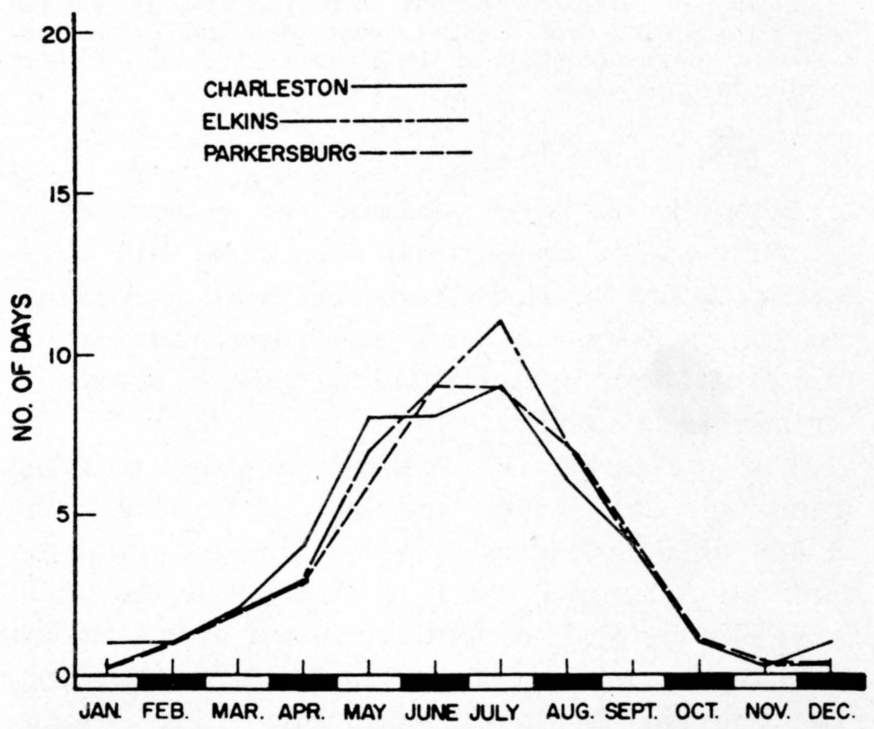

Figure 31. Average number of thunderstorm days per month, Charleston, Elkins and Parkersburg, West Virginia. 
TABLE 2

HOURLY PRECIPITATION DATA FROM CHARLESTON, WEST VIRGINIA FOR

THE YEARS 1955 THROUGH 1967

\begin{tabular}{|c|c|c|c|c|c|c|c|c|c|}
\hline $\begin{array}{c}\text { Hour } \\
\text { Of Day }\end{array}$ & \multicolumn{4}{|c|}{$\begin{array}{l}\text { Average No. of Hours/Month with } \\
\text { Precipitation }=.01 \text { Inch or More }\end{array}$} & & \multicolumn{4}{|c|}{$\begin{array}{l}\text { Average Amount of Hourly } \\
\text { Precipitation/Month (Inches) }\end{array}$} \\
\hline $\begin{array}{ll}1 & \text { a.m. } \\
2 & \text { a.m. } \\
3 & \text { a.m. } \\
4 & \text { a.m. } \\
5 & \text { a.m. } \\
6 & \text { a.m. }\end{array}$ & $\begin{array}{l}\text { Jan. } \\
3.9 \\
4.6 \\
5.0 \\
3.8 \\
3.5 \\
2.9\end{array}$ & $\begin{array}{c}\text { Apr. } \\
2.1 \\
3.2 \\
3.1 \\
3.2 \\
3.1 \\
2.6\end{array}$ & $\begin{array}{c}\text { July } \\
1.8 \\
2.1 \\
1.6 \\
1.5 \\
1.4 \\
2.2\end{array}$ & $\begin{array}{l}\text { Oct. } \\
1.7 \\
1.8 \\
1.6 \\
1.4 \\
1.7 \\
1.7\end{array}$ & & $\begin{array}{l}\text { Jan. } \\
.15 \\
.21 \\
.19 \\
.14 \\
.14 \\
.14\end{array}$ & $\begin{array}{c}\text { Apr. } \\
.08 \\
.16 \\
.15 \\
.12 \\
.14 \\
.14\end{array}$ & $\begin{array}{c}\text { July } \\
.12 \\
.19 \\
.13 \\
.09 \\
.22 \\
.19\end{array}$ & $\begin{array}{l}\text { Oct. } \\
.07 \\
.08 \\
.08 \\
.09 \\
.07 \\
.10\end{array}$ \\
\hline $\begin{aligned} 7 & \text { a.m. } \\
8 & \text { a.m. } \\
9 & \text { a.m. } \\
10 & \text { a.m. } \\
11 & \text { a.m. } \\
12 & \text { noon }\end{aligned}$ & $\begin{array}{l}2.7 \\
4.4 \\
4.6 \\
4.4 \\
4.1 \\
3.1\end{array}$ & $\begin{array}{l}3.3 \\
3.9 \\
3.8 \\
3.6 \\
3.4 \\
3.2\end{array}$ & $\begin{array}{l}1.7 \\
1.8 \\
1.7 \\
1.7 \\
1.6 \\
1.8\end{array}$ & $\begin{array}{l}1.9 \\
2.2 \\
2.1 \\
1.8 \\
1.5 \\
1.5\end{array}$ & $\begin{array}{l}\text { NOTE: All hours } \\
\text { Eastern Standard } \\
\text { Time (EST). }\end{array}$ & $\begin{array}{l}.14 \\
.25 \\
.22 \\
.18 \\
.12 \\
.12\end{array}$ & $\begin{array}{l}.17 \\
.19 \\
.19 \\
.17 \\
.12 \\
.14\end{array}$ & $\begin{array}{l}.13 \\
.09 \\
.14 \\
.14 \\
.28 \\
.26\end{array}$ & $\begin{array}{l}.08 \\
.10 \\
.09 \\
.08 \\
.09 \\
.08\end{array}$ \\
\hline $\begin{array}{ll}1 & \text { p.m. } \\
2 & \text { p.m. } \\
3 & \text { p.m. } \\
4 & \text { p.m. } \\
5 & \text { p.m. } \\
6 & \text { p.m. }\end{array}$ & $\begin{array}{l}2.5 \\
2.6 \\
3.1 \\
3.3 \\
4.1 \\
4.4\end{array}$ & $\begin{array}{l}2.9 \\
3.1 \\
2.8 \\
3.5 \\
3.4 \\
2.9\end{array}$ & $\begin{array}{l}2.4 \\
2.0 \\
2.2 \\
2.4 \\
2.6 \\
2.6\end{array}$ & $\begin{array}{l}1.7 \\
1.7 \\
1.7 \\
1.8 \\
2.1 \\
2.1\end{array}$ & - & $\begin{array}{l}.10 \\
.11 \\
.11 \\
.10 \\
.12 \\
.15\end{array}$ & $\begin{array}{l}.20 \\
.17 \\
.19 \\
.21 \\
.20 \\
.16\end{array}$ & $\begin{array}{l}.22 \\
.26 \\
.36 \\
.32 \\
.50 \\
.26\end{array}$ & $\begin{array}{l}.11 \\
.09 \\
.14 \\
.08 \\
.13 \\
.11\end{array}$ \\
\hline $\begin{aligned} 7 & \text { p.m. } \\
8 & \text { p.m. } \\
9 & \text { p.m. } \\
10 & \text { p.m. } \\
11 & \text { p.m. } \\
12 & \text { mid. }\end{aligned}$ & $\begin{array}{l}4.1 \\
3.7 \\
3.5 \\
4.0 \\
4.0 \\
3.6\end{array}$ & $\begin{array}{l}2.6 \\
2.6 \\
2.4 \\
2.1 \\
2.1 \\
2.1\end{array}$ & $\begin{array}{l}2.4 \\
1.9 \\
2.0 \\
1.1 \\
1.1 \\
1.4\end{array}$ & $\begin{array}{l}1.7 \\
1.9 \\
1.4 \\
2.0 \\
2.0 \\
2.0\end{array}$ & & $\begin{array}{l}.16 \\
.17 \\
.12 \\
.13 \\
.13 \\
.13\end{array}$ & $\begin{array}{l}.09 \\
.10 \\
.13 \\
.15 \\
.17 \\
.08\end{array}$ & $\begin{array}{l}.26 \\
.36 \\
.33 \\
.22 \\
.21 \\
.32\end{array}$ & $\begin{array}{l}.10 \\
.13 \\
.07 \\
.07 \\
.10 \\
.10\end{array}$ \\
\hline Sum: All Hrs. & 89.9 & 71.0 & 45.3 & 42.7 & 1955-1967 Average: & 3.53 & 3.62 & 5.60 & 2.24 \\
\hline Per Cent & $12.1 \%$ & $9.9 \%$ & $6.1 \%$ & $5.7 \%$ & 1931-1960 Normal: & 4.32 & 3.68 & 5.67 & 2.58 \\
\hline
\end{tabular}

Midseason values on the left show that January has the greatest number of hours with precipitation with little difference between nighttime and daytime hours. July and October have the least number of hours with precipitation, with July showing a greater number of hours in the afternoon and early evening. Values on the right show larger amounts during the afternoon and evening for July also.

Flooding of larger streams and watersheds is generally a cold season event associated with largescale cyclonic storms. December to April is the high risk season. A saturated soil, snow cover, warm steady rains, and high humidity are the usual ingredients for large-scale floods.

For prevention of excessive damage resulting from high runoff rates and high water stages, the design of dams, locks, ditches, culverts, pumping rates, ground slopes, etc. must incorporate the likelihood of occurrence of extreme runoff events against the cost of building larger and/or safer structures. The frequency of occurrence of flood stage is sometimes available for gaged streams but more often must be evaluated through the use of precipitation analysis. Table 3 is such an analysis for Charleston, West Virginia. It lists the precipitation amounts for one-hour, one-day and ten-day events that are likely to be equalled or exceeded once on the average for return periods of $2,5,10,25,50$ and 100 years (6).

The distribution of snowfall throughout the State (Figure 32) is similar to that for average annual precipitation (Figure 22) except that the range of totals is more extreme which reinforces the relationship of topography to precipitation accumulations. The distribution of annual snowfall has a great range of values - from 20 inches in the Ohio River Basin to over 160 inches in the northern mountain areas. Monthly snowfall maps for November through March are presented singly in Figures 33, 34, 35, 36, and 37. As expected, the coldest month, January, has the highest accumulation of snow though it is not exceptionally different from that of other cold months. 
TABLE 3

RETURN PERIOD VALUE IN INCHES OF PRECIPITATION FOR SELECTED DURATIONS AT CHARLESTON, WEST VIRGINIA

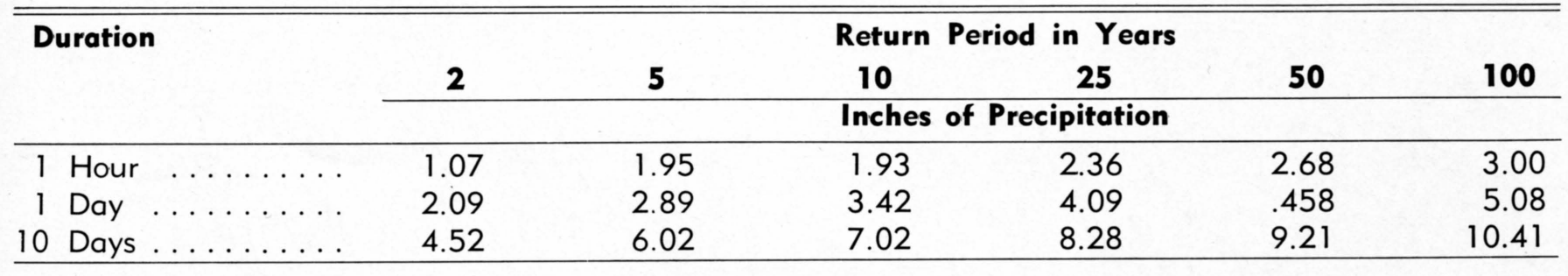

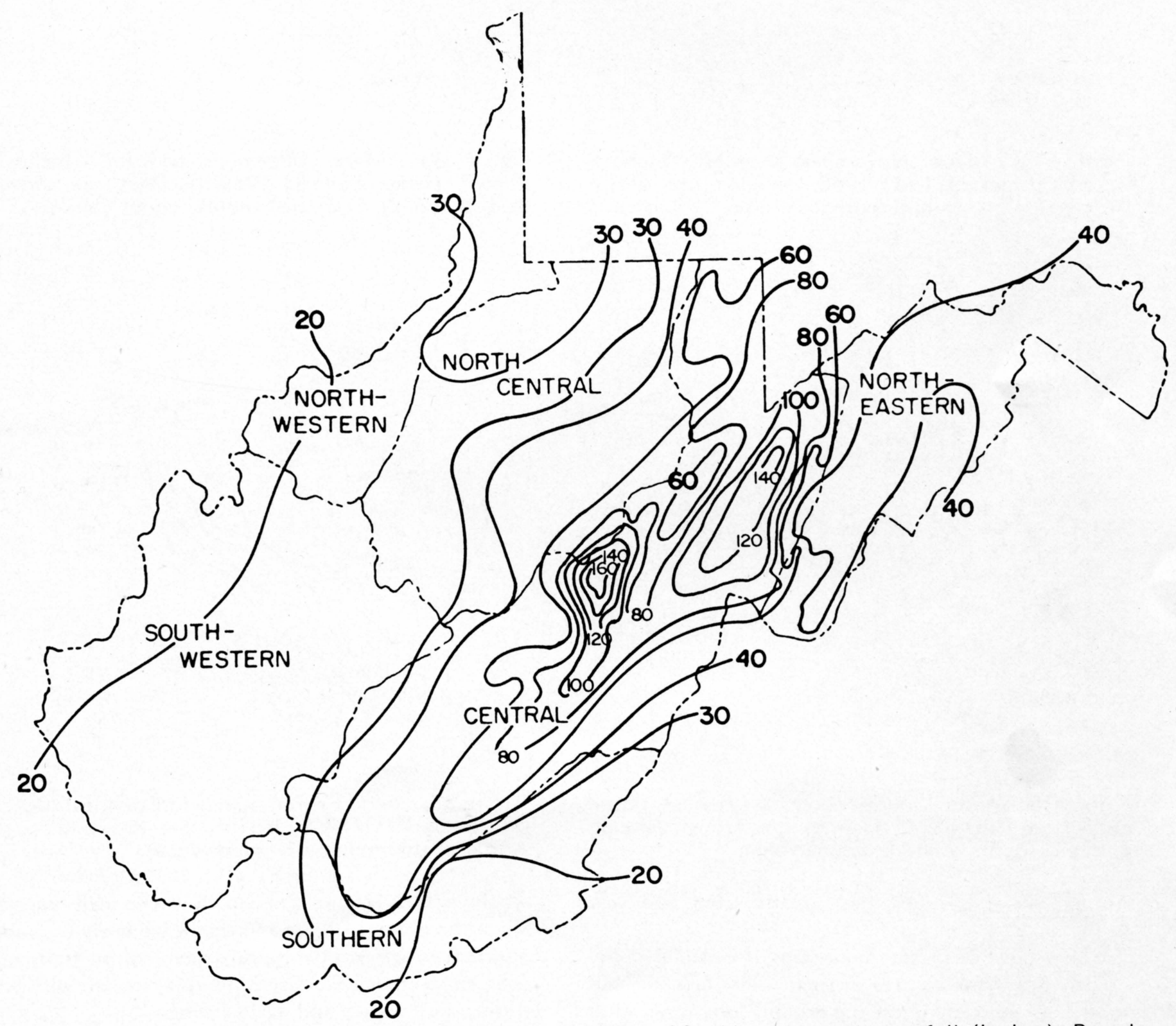

Figure 32. Mean annual snowfall (Inches). Based on period 1931-1960. Isolines are drawn through points of approximately equal value. 


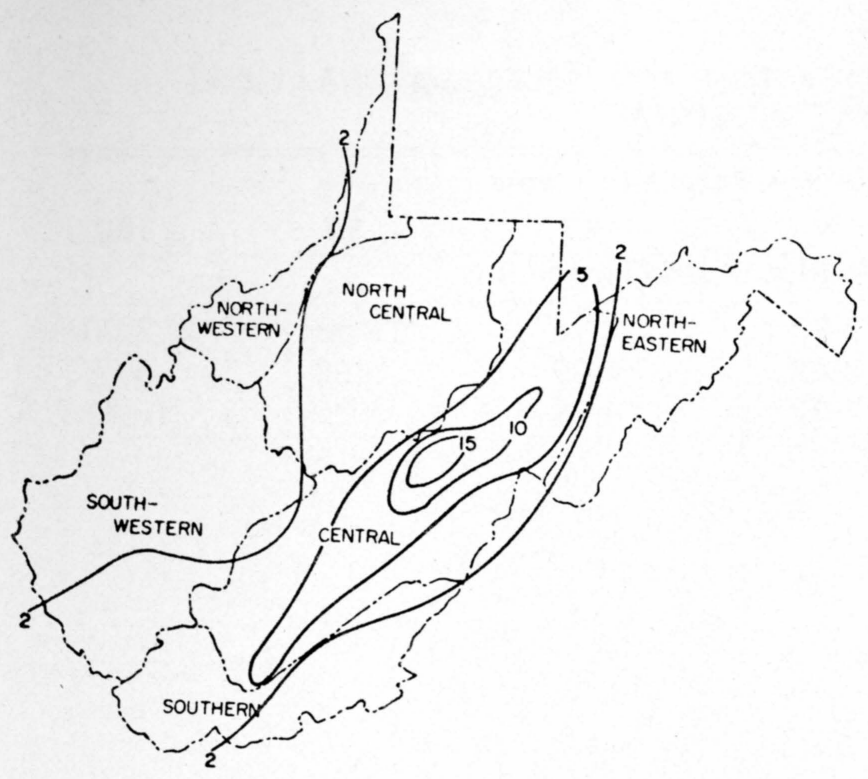

Figure 33. Mean November snowfall (Inches). Based on period 1931-1960. Isolines are drawn through points of approximately equal value.

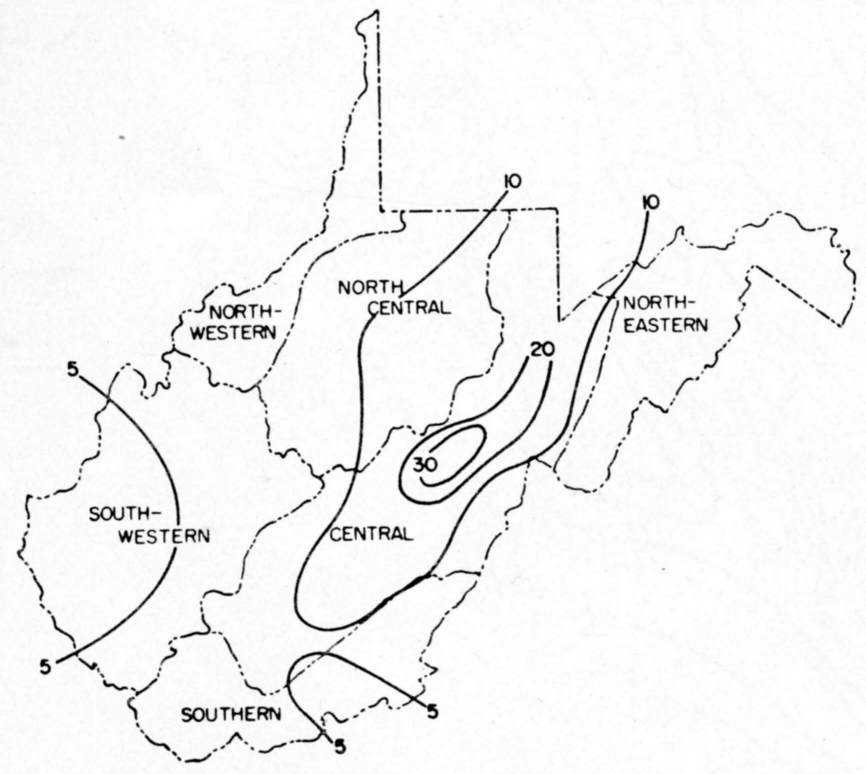

Figure 35. Mean January snowfall (Inches). Based on period 1931-1960. Isolines are drawn through points of approximately equal value.

Annual snowfall totals vary greatly from one year to the next.

The snowfall in the mountains is considered unusually heavy for an area at such a low latitude, but snow does not remain on the ground long, even after a heavy fall. Snow does accumulate in the high mountains but usually does not last uninterrupted for the

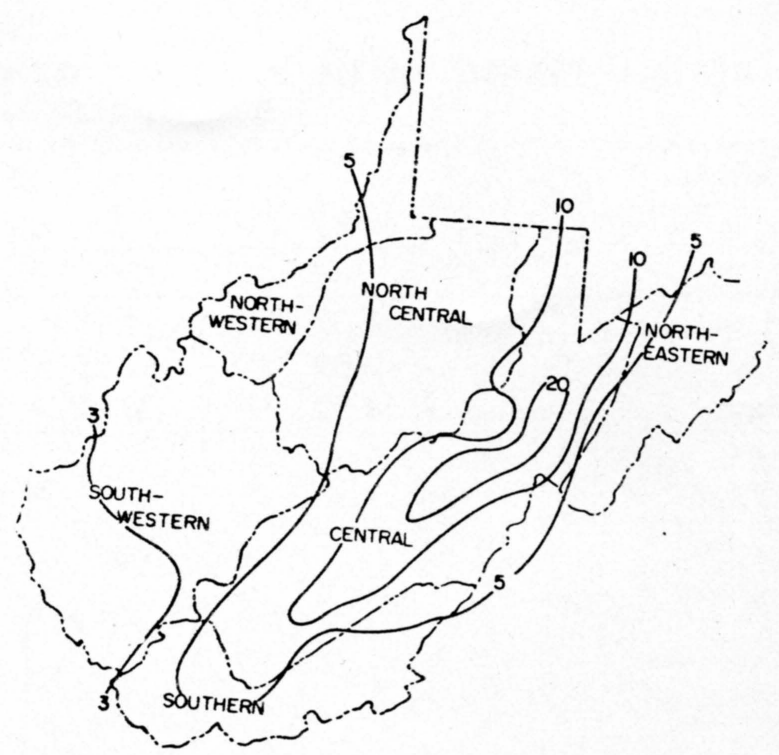

Figure 34. Mean December snowfall (Inches). Based on period 1931-1960. Isolines are drawn through points of approximately equal value.

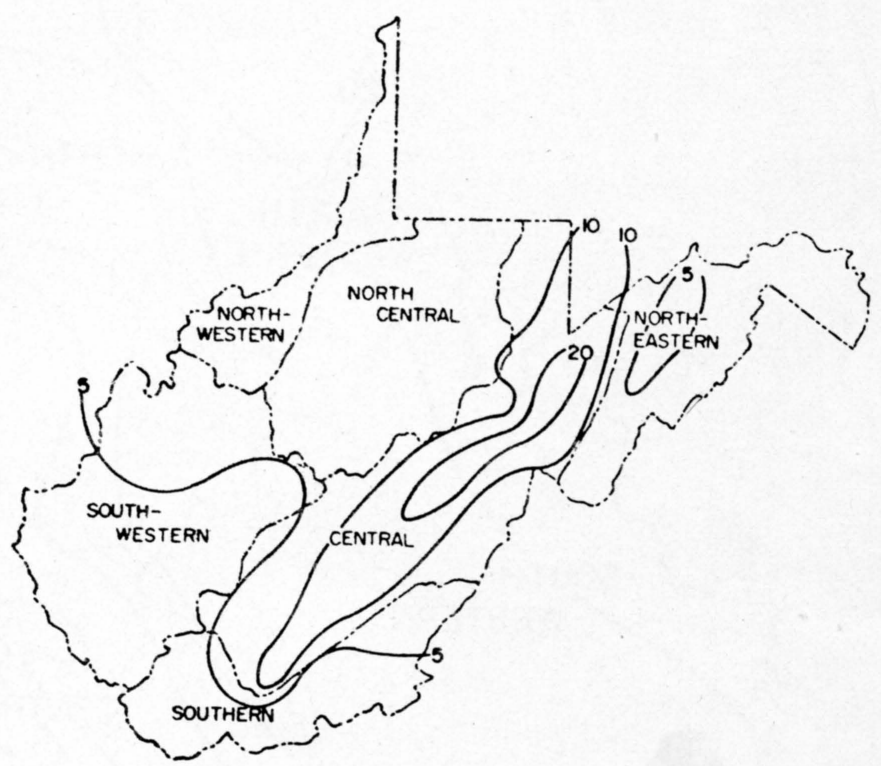

Figure 36. Mean February snowfall (Inches). Based on period 1931-1960. Isolines are drawn through points of approximately equal value.

whole winter season. Periods of snow melt and/or when the ground freezes and thaws are fairly common and make logging operations dependent on transport over unpaved or unimproved roads extremely difficult during late winter and early spring.

The snow cover map (Figure 38) shows the number of days with snow cover equal to or greater than 


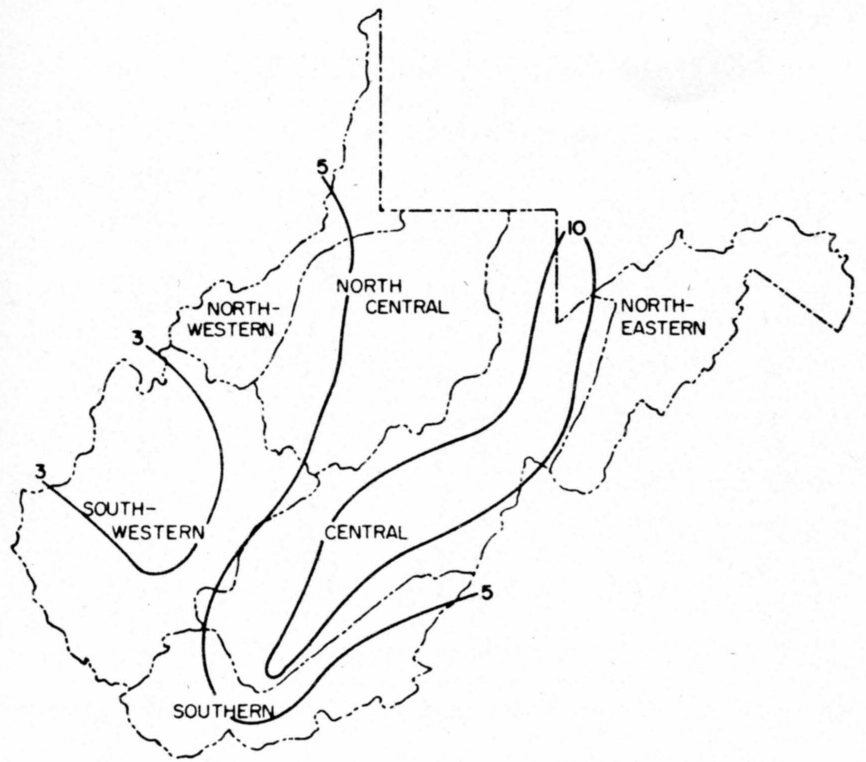

Figure 37. Mean March snowfall (Inches). Based on period 1931-1960. Isolines are drawn through points of approximately equal value.

one inch. Weather stations in the northern mountains averaged about 70 days, but elevations above 3,500 feet where data is unavailable and north-facing hillslopes undoubtedly have considerably more days with snow cover.

Tables $4 \mathrm{a}$ and $4 \mathrm{~b}$ show the one-day snowfall amounts expected for return periods of 2 to 100 years, and the accumulated snow depth expected to occur once on the average during periods of 2 to 100 years (8). Snow removal capabilities of road crews for each county could be designed around this sort of data, allocating personnel, materials, and equipment to handle the expected load.

\section{Drying Trends}

Drought, evaporation and transpiration potentials are of considerable consequence to many weather dependent activities in agriculture, forestry, industry and recreation (7). A map of potential evapotranspiration (after Thornthwaite, 21) for the growing season (Figure 39) points out a slightly lower potential of 20 inches for the mountainous Central Climatic Division compared with 23 inches for the Northeastern and 24 for the Southwestern Climatic Divisions. Evaporation is highest during the month of July and is relatively uniform for the stations listed (26). Pan evaporation presented in Figure 40, is related to water losses from ponds and reservoirs.

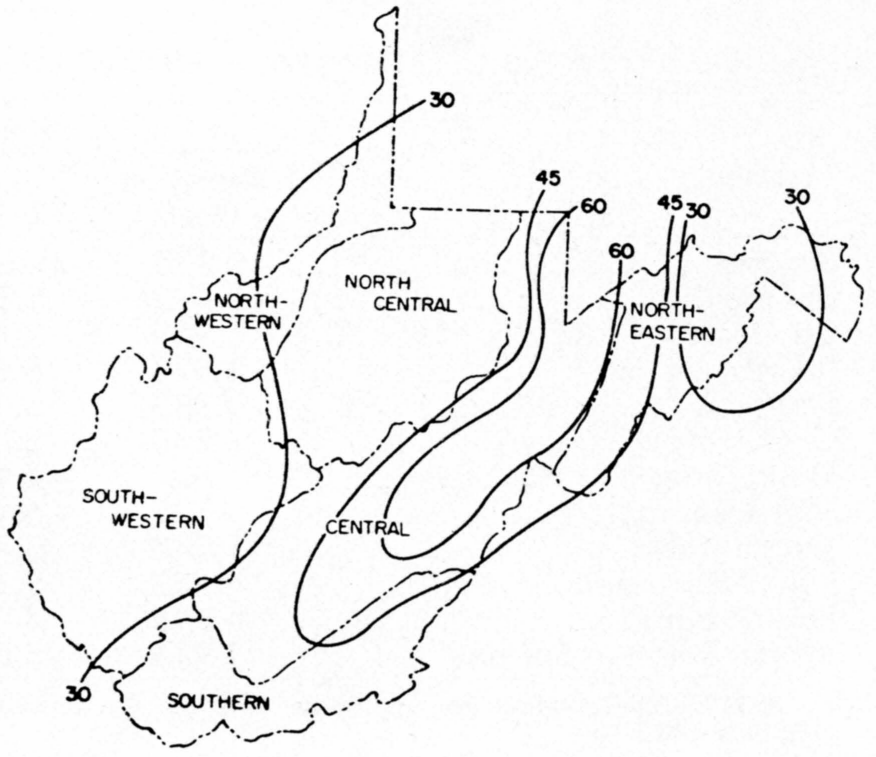

Figure 38. Snow cover map. Average number of days per year, depth of snow cover is one inch or more.

In West Virginia, evaporation from reservoirs is about 70 per cent of pan evaporation (15) .

A serious matter for all concerned with water supply is the persistence of drought conditions (7), (10) and the frequency of occurrence (see Table 5). Concurrent with prolonged drought conditions is

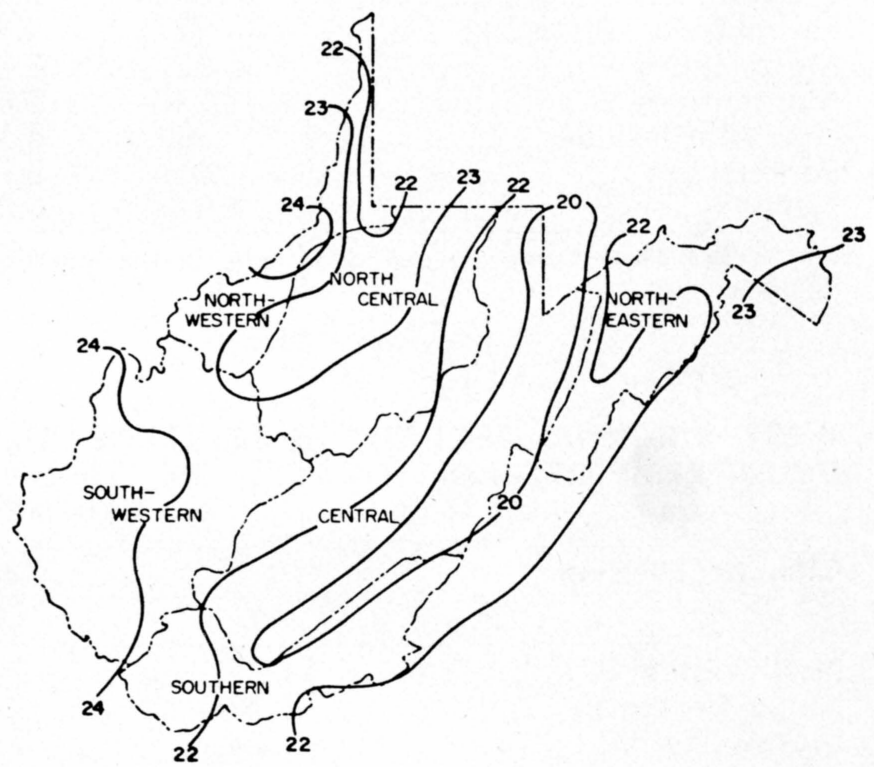

Figure 39. Potential evapotranspiration (Inches), after Thornthwaite during growing season (May through October). Based on period 1931-1960. Isolines are drawn through points of approximately equal value. 